\title{
Phosphorus recycling in photorespiration maintains high photosynthetic capacity in woody species
}

DAVID S. ELLSWORTH ${ }^{1,}{ }^{*}$, KRISTINE Y. CROUS ${ }^{1}$, HANS LAMBERS ${ }^{2}$, JULIA COOKE ${ }^{1,3}$

1 Hawkesbury Institute for the Environment, Locked Bag 1797, University of Western Sydney, Penrith, NSW, 2751, Australia

2 School of Plant Biology, The University of Western Australia, 35 Stirling Highway, Crawley (Perth), WA 6009, Australia

${ }^{3}$ Department of Biological Sciences, Faculty of Science, Macquarie University, North Ryde, NSW 2109, Australia

*Corresponding author (D.Ellsworth@.uws.edu.au)

Received: $18^{\text {th }}$ September 2014

Running Head: PHOSPHORUS RECYCLING IN PHOTORESPIRATION

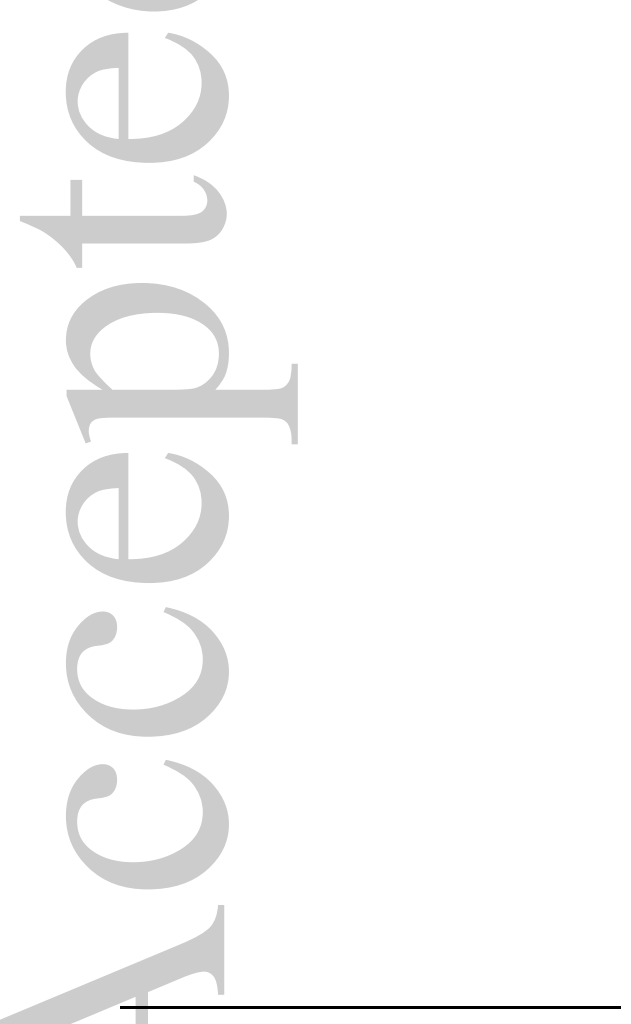

This article has been accepted for publication and undergone full peer review but has not been through the copyediting, typesetting, pagination and proofreading process, which may lead to differences between this version and the Version of Record. Please cite this article as doi: 10.1111/pce.12468

This article is protected by copyright. All rights reserved. 
3 Leaf photosynthetic $\mathrm{CO}_{2}$ responses can provide insight into how major nutrients

4 such as phosphorus $(\mathrm{P})$ constrain leaf $\mathrm{CO}_{2}$-assimilation rates $\left(A_{\text {net }}\right)$. However,

5 triose-phosphate limitations are rarely employed in the classic photosynthesis

6 model and it is uncertain to what extent these limitations occur in field situations.

7 In contrast to predictions from biochemical theory of photosynthesis, we found

8 consistent evidence in the field of lower $A_{\text {net }}$ in high $\left[\mathrm{CO}_{2}\right]$ and low $\left[\mathrm{O}_{2}\right]$ than at

9 ambient $\left[\mathrm{O}_{2}\right]$. For ten species of trees and shrubs across a range of soil $P$

10 availability in Australia, none of them showed a positive response of $\boldsymbol{A}_{\text {net }}$ at

11 saturating [ $\left[\mathrm{CO}_{2}\right]$ (i.e. $A_{\max }$ ) to $2 \mathrm{kPa} \mathbf{0}_{2}$. Three species showed $>\mathbf{2 0 \%}$ reductions in

$12 A_{\max }$ in low $\left[\mathrm{O}_{2}\right]$, a phenomenon explained by orthophosphate $\left(\mathrm{P}_{\mathrm{i}}\right)$ savings during

13 photorespiration. These species, with largest photosynthetic capacity and $P_{i}>2$

$14 \mathbf{m m o l} \mathbf{P ~ m}^{-2}$, rely the most on additional $P_{i}$ made available from photorespiration

15 rather than species growing in P-impoverished soils. The results suggest that

16 rarely-used adjustments to a biochemical photosynthesis model are useful for

17 predicting $A_{\max }$, and give insight into the biochemical limitations of photosynthesis rates at a range of leaf $P$ concentrations. Phosphate limitations to photosynthetic capacity are likely more common in the field than previously

20 considered.

21

1

This article is protected by copyright. All rights reserved. 


\section{INTRODUCTION}

The net $\mathrm{CO}_{2}$-assimilation rate $\left(A_{\text {net }}\right)$ of $\mathrm{C}_{3}$ leaves in sunlight comprises three principal processes occurring at the same time: photosynthesis, photorespiration and mitochondrial respiration in the light. A major theoretical advance in the ability to understand and model leaf and canopy $\mathrm{CO}_{2}$ exchange incorporating elements of all three processes was afforded by the biochemical model of photosynthesis of Farquhar et al. (1980), further described in von Caemmerer (2000). This model, originally formulated environmental constraints (Long \& Bernacchi 2003). The original FvCB model (Farquhar et al. 1980) and its subsequent modifications (Sharkey 1985; Sharkey et al. by Farquhar et al. (1980) (here termed the FvCB model) allows for inferences to be made about biochemical limitations to leaf and canopy functioning, overlain by 2007; von Caemmerer 2000) successfully predicts photosynthesis under a very wide range of conditions, and has been applied to scales ranging from the chloroplast (von Caemmerer 2013) to forest canopies (Groenendijk et al. 2011) and biomes (Bonan et al. 2011; Kattge et al. 2009). A unique element of the FvCB model is the ability to estimate photorespiratory $\mathrm{CO}_{2}$ efflux concurrent with photosynthetic $\mathrm{CO}_{2}$ influx as component processes contributing to the net $\mathrm{CO}_{2}$-assimilation rate of leaves (Busch 2013; Sage \& Sharkey 1987). Both component processes need to be considered to predict net $\mathrm{CO}_{2}$ assimilation as they occur at the same time, and together have implications for predicting the response of leaf $\mathrm{CO}_{2}$ assimilation to rising atmospheric $\mathrm{CO}_{2}$ concentrations, given that elevated $\left[\mathrm{CO}_{2}\right]$ both stimulates photosynthesis and suppresses photorespiration (Sharkey 1988; von Caemmerer 2000).

The FvCB biochemical model of photosynthesis has provided a useful context for interpreting many mechanistic aspects of plant function, including how the availability of major nutrients to plant canopies can restrict photosynthetic capacity and net primary productivity (Kattge et al. 2009). Analyses of nitrogen (N) limitations to photosynthetic capacity have been based on the fact that a major fraction of leaf $\mathrm{N}$ is allocated to the Rubisco enzyme (Evans 1989). The large proportion of leaf $N$ invested in Rubisco and related photosynthetic proteins means that two major parameters of the FBvC model, the maximum carboxylation rate $\left(V_{\text {cmax }}\right)$ and the capacity for electron transport to support RuBP regeneration $\left(U_{\max }\right)$, tend to scale linearly with leaf $[\mathrm{N}]$ in herbaceous crop species (Archontoulis et al. 2012; Evans 1989) and in woody species

This article is protected by copyright. All rights reserved. 

(Ellsworth et al. 2004; Rogers 2014). Such relationships are now used in a number of ecosystem and global-scale models to assess ecosystem productivity of $\mathrm{N}$-limited ecosystems (Piao et al. 2013; Rogers 2014; Williams et al. 1997; Zaehle et al. 2014). However, P limitation of plant productivity is also widespread, with up to one-third of the world's soil orders demonstrating low P availability (Yang \& Post 2011). In contrast to $\mathrm{N}$, it is less clear how low leaf $\mathrm{P}$ concentration in P-limited systems may affect photosynthetic biochemistry. There are suggestions of both direct and indirect roles of P regulating $A_{\text {net }}$ (Domingues et al. 2010; Pieters et al. 2001; Thomas et al. 2006). Hence, a mechanistic representation of $\mathrm{P}$ limitations to leaf $\mathrm{CO}_{2}$ assimilation is rarely implemented in either leaf-to-canopy (Bernacchi et al. 2013; Long \& Bernacchi 2003; Manter \& Kerrigan 2004) or large-scale models (Wang et al. 2010), despite the importance of $\mathrm{P}$ as a major limiting element across tropical, subtropical and some temperate ecosystems (Aerts \& Chapin 2000; Lambers et al. 2010; Vitousek et al. 2010). Low P supply from soils can affect bulk leaf P concentration and decrease leaf orthophosphate $\left(\mathrm{P}_{\mathrm{i}}\right)$ pools as well as reduce leaf net $\mathrm{CO}_{2}$-assimilation rate and other components of photosynthetic biochemistry (Hammond \& White 2011; Veneklaas et al. 2012). Since P-containing molecules such as ATP, NADPH, and sugar-phosphates including ribulose-1,5-bisphosphate (RuBP) have key roles in the Calvin-Benson cycle, lack of sufficient $\mathrm{P}$ and $\mathrm{P}_{\mathrm{i}}$ would be expected to limit the maximum light- and $\mathrm{CO}_{2}$ saturated $A_{\text {net }}\left(A_{\max }\right)$ that can be achieved in leaves (Brooks 1986; Loustau et al. 1999).

75 Such a decrease in the concentration of these metabolites upon P starvation is typical for plants that are not adapted to P-impoverished soils. Conversely, Proteaceae from severely P-impoverished soils in Australia do not operate at lower leaf P metabolite concentrations at very low soil $\mathrm{P}$ availability, but rather replace phospholipids by galactolipids and sulfolipids (Lambers et al. 2012) and operate at very low levels of ribosomal RNA and proteins (Sulpice et al. 2014). Still, P-limitation might be manifest in limiting RuBP regeneration as the underlying control over $A_{\max }$ in leaves (Campbell \& Sage 2006; Jacob \& Lawlor 1993). Whilst evidence for RuBP regeneration limitation by low $\mathrm{P}_{\mathrm{i}}$ exists in laboratory studies (Jacob \& Lawlor 1993), the mechanism by which low leaf [P] decreases photosynthetic capacity is not well defined and field evidence of such limitations is still lacking.

One approach for quantifying P-limitations to the biochemistry of net $\mathrm{CO}_{2}$ assimilation is by estimating triose-P limitations following theory proposed by Sharkey

This article is protected by copyright. All rights reserved. 

(1985). The basis of this theory is that RuBP regeneration is adenylate-limited, and a release from this limitation is achieved by the release of $\mathrm{P}_{\mathrm{i}}$ associated with precursors for sucrose synthesis in the cytosol. Exchange of each released $\mathrm{P}_{\mathrm{i}}$ for triose-P produced

91 in the chloroplast allows continued triose-P export to the cytosol (Paul \& Foyer 2001;

92 Stitt et al. 2010; see A in Fig. 1). An alternative hypothesis is that triose-P limitation is related to how 'closed' the photorespiratory cycle is with regard to the return of glycerate to the chloroplast via photorespiratory glycolate metabolism in the peroxisomes and mitochondria (Harley \& Sharkey 1991; Fig. 1, highlighted as B). Shortterm low-photorespiratory conditions using low $\mathrm{O}_{2}$ partial pressure in air $\left(\mathrm{pO}_{2}\right)$ can be used as a probe of these biochemical limitation mechanisms to $A_{\text {net. }}$. However, whilst triose-P limitations are often mentioned in publications describing the $\mathrm{FBvC}$ photosynthesis model, they are rarely parameterised (Bernacchi et al. 2013; Manter \& Kerrigan 2004), except in very few studies where plants are grown at very low P supply (Bown et al. 2009; Domingues et al. 2010; Loustau et al. 1999). To investigate P limitations to photosynthetic capacity in the field, we sought to determine if these limitations have a role in regulating the biochemical processes underlying leaf $A_{\text {net }}$ in the field. We specifically asked $i$ ) if the standard two-limitation version of the FvCB model (Farquhar et al. 1980; Farquhar et al. 2001) is adequate to characterise the major parameters controlling photosynthetic capacity for species growing at a range of leaf $\mathrm{P}$ and $\mathrm{P}_{\mathrm{i}}$ concentrations, $\mathrm{ii}$ ) is there evidence of triose- $\mathrm{P}$ limitations to $A_{\text {net }}$ using non-photorespiratory gas exchange analysis, and iii) are trioseP-utilisation limitations to $A_{\text {net }}$ associated with concentrations of bulk leaf P or $\mathrm{P}_{\mathrm{i}}$ ? Our null hypothesis was that leaf photosynthetic capacity at both normal (ambient $\mathrm{pO}_{2}$ of 21 $\mathrm{kPa}$ ) and low $\mathrm{pO}_{2}$ could be described adequately by the two-limitation version of the FvCB model. In this study we used the tool of providing nearly non-photorespiratory leaf $A_{\text {net. }}$ This was done for Australian sclerophyll plants at a range of leaf P levels in both eastern and south-western Australia, including locations characterised by some of the lowest soil P availabilities on earth (Lambers et al. 2010) as well as sites with moderate $\mathrm{P}$ availability. In so doing, we sought to resolve whether plants with low leaf $\mathrm{P}$ were more likely to show triose-P limitations than those at higher leaf P levels, an idea that is occasionally cited (see Domingues et al. 2010; Loustau et al. 1999). We chose a set of native species that included species of Eucalyptus and Acacia and species in the

This article is protected by copyright. All rights reserved. 

styraciflua L. which is not native to Australia or similarly low-P soils.

\section{METHODS AND THEORIES}

Theory from the Farquhar et al. (1980) photosynthesis model

Analysis of the instantaneous response of leaf net photosynthesis to brief changes in the $\mathrm{CO}_{2}$ concentration surrounding leaves underpins the $\mathrm{FBvC}$ model parameterisation

127 (Long \& Bernacchi 2003; von Caemmerer 2000). According to the standard FvCB model 128 based on the stoichiometry of carbon in photosynthesis and photorespiration (Farquhar et al. 1980; von Caemmerer 2000), the net $\mathrm{CO}_{2}$-assimilation rate of a leaf $\left(A_{\text {net }}\right)$ can be expressed as

$131 \mathrm{~A}_{\text {net }}=v_{c}-0.5 v_{o}-\mathrm{R}_{\mathrm{d}}=v_{c}\left(1-\Gamma^{*} / C_{i}\right)-\mathrm{R}_{\mathrm{d}}$

132 with $v_{\mathrm{c}}$ and $v_{\mathrm{o}}$ denoting the carboxylation and oxygenation rates of the Rubisco enzyme, $R_{d}$ representing the rate of mitochondrial respiration in the light, $\Gamma^{*}$ representing the

$134 \mathrm{CO}_{2}$ concentration at which the photorespiratory efflux of $\mathrm{CO}_{2}$ equals the rate of 135 photosynthetic $\mathrm{CO}_{2}$ uptake, and $C_{\mathrm{i}}$ indicating the internal $\mathrm{CO}_{2}$ concentration in the substomatal cavity. As there is also a liquid-phase resistance between the intercellular surfaces and the sites of carboxylation in the thylakoids, this equation is best expressed using $C_{\mathrm{c}}$, the chloroplastic $\mathrm{CO}_{2}$ concentration, rather than $C_{\mathrm{i}}$ thus incorporating mesophyll conductance to $\mathrm{CO}_{2}$ transfer in the liquid phase (Pons et al. 2009). Thus, carboxylation rate and hence $A_{\text {net }}$ is limited by one of two rates, $W_{\mathrm{c}}$ and $W_{\mathrm{j}}$ (Farquhar et al. 1980), later revised to include a third rate-limiting process $W_{\mathrm{t}}$ (Sharkey 1985): $W_{\mathrm{c}}$ is the carboxylation-limited rate of net $\mathrm{CO}_{2}$ assimilation when chloroplastic $\mathrm{RuBP}$ is saturating, $W_{\mathrm{j}}$ is the energy transduction for ATP synthesis leading to the subsequent regeneration of ribulose 1,5-bisphosphate (RuBP) in the photosynthetic carbonreduction cycle, and $W_{\mathrm{t}}$ is the net $\mathrm{CO}_{2}$-assimilation rate when triose-P pools tie up the available orthophosphate $\left(\mathrm{P}_{\mathrm{i}}\right)$ for synthesising ATP needed in the photosynthetic carbon reduction or Calvin-Benson cycle (Bernacchi et al. 2013; Sharkey et al. 2007). When Rubisco activity limits photosynthetic $\mathrm{CO}_{2}$ assimilation $\left(W_{\mathrm{c}}\right), A_{\text {net }}$ is given 150 by

151

$$
\mathrm{A}_{\text {net }}=V_{c \max } \frac{C_{\mathrm{c}}-\Gamma^{*}}{\left(C_{\mathrm{c}}+K^{\prime}\right)}-\mathrm{R}_{\mathrm{d}}
$$

This article is protected by copyright. All rights reserved. 

where the half-saturation constant $K^{\prime}=\mathrm{k}_{\mathrm{c}}\left(1+O_{i} / \mathrm{k}_{\mathrm{o}}\right)$. Here $V_{\mathrm{cmax}}$ is the maximum catalytic activity of Rubisco with saturating $\mathrm{RuBP}, C_{\mathrm{c}}$ and $O_{\mathrm{i}}$ are the chloroplastic $\mathrm{CO}_{2}$ and intercellular $\mathrm{O}_{2}$ gas partial pressures, respectively, and $\mathrm{k}_{\mathrm{c}}$ and $\mathrm{k}_{\mathrm{o}}$ are the MichaelisMenten coefficients of Rubisco for $\mathrm{CO}_{2}$ and $\mathrm{O}_{2}$ (see Bernacchi et al. 2013; Sharkey et al. 2007). The photosynthetic $\mathrm{CO}_{2}$-compensation point $\left(\Gamma^{*}\right)$ is the $\mathrm{CO}_{2}$ concentration at which the photorespiratory efflux of $\mathrm{CO}_{2}$ equals the rate of photosynthetic $\mathrm{CO}_{2}$ assimilation. Given that the Rubisco enzyme is characterised by relatively conservative kinetic properties among different lineages of higher $\mathrm{C}_{3}$ plant species, $\mathrm{k}_{\mathrm{c}}, \mathrm{k}_{0}$ and $\Gamma^{*} \mathrm{can}$ be assumed as relatively invariant among species (Bernacchi et al. 2001; but see Galmés et al. 2005; Walker et al. 2013). In the classic version of the FvCB model, when $C_{\mathrm{c}}$ is close to saturation for photosynthesis such that RuBP regeneration limits photosynthesis ( $W_{\mathrm{j}}$ is limiting), $A_{\text {net }}$ is given by

$$
\mathrm{A}_{\text {net }}=J_{\max } \frac{C_{\mathrm{c}}-\Gamma^{*}}{\left(4 C_{\mathrm{c}}+8 \Gamma^{*}\right)}-\mathrm{R}_{\mathrm{d}}
$$

where $J_{\max }$ is the maximum rate of electron transport at saturating quantum flux density to provide energy for RuBP regeneration in the PCR cycle. Most frequently, the parameters $V_{\text {cmax }}$ and $J_{\max }$ are investigated as the major components of the photosynthesis model (Cernusak et al. 2011; Kattge et al. 2009; Rogers 2014; Walker et al. 2014) assuming two major biochemical limitations to $A_{\text {net. }}$ However, as originally stated, the FvCB photosynthesis model has no explicit dependence of $J_{\max }$ on $\mathrm{O}_{2}$ partial pressure except $\Gamma^{*}$ in Eqn 4. The $\Gamma^{*}$ term is a function of the in vivo substrate specificity

172 factor for the Rubisco enzyme $\left(S_{\mathrm{c} / \mathrm{o}}\right)$, given as:

$$
\Gamma^{*}=\frac{0.5 \cdot O}{S_{c / o}}
$$

174 Where $S_{\mathrm{c} / \mathrm{o}}$ is here considered $\approx 92 \mathrm{~mol} \mathrm{~mol}^{-1}$ at $25^{\circ} \mathrm{C}$, within the range reported for $\mathrm{C}_{3}$ woody species (Galmés et al. 2005). The original version of the FvCB photosynthesis model produces predictions of the $A_{\text {net }}-C_{\mathrm{c}}$ response at normal air $\mathrm{pO}_{2}(21 \mathrm{kPa}$, hereafter

177 referred to as normal $\mathrm{pO}_{2}$ ) and low-photorespiratory $\mathrm{pO}_{2}$ that are illustrated in Fig. 2 178 (see also von Caemmerer 2000).

\section{FvCB photosynthesis model with triose-phosphate limitation included}

This article is protected by copyright. All rights reserved. 

Two modifications of the original FvCB model were subsequently proposed to account for the behaviour of $A_{\text {net }}$ measured at high $\mathrm{CO}_{2}$ partial pressures and with suppression of photorespiration at experimentally reduced $\mathrm{O}_{2}$ partial pressures. These changes to the model accounted for two physiological states that have been observed both at high $\mathrm{CO}_{2}$ partial pressures: i) $\mathrm{O}_{2}$ insensitivity of $A_{\text {net }}$ at high $\mathrm{pCO}_{2}$, and ii) reverse $\mathrm{O}_{2}$ sensitivity of $A_{\text {net. }}$ In the first version, synthesis of sucrose from triose-phosphates was thought to make a contribution to $\mathrm{P}_{\mathrm{i}}$ recycling for photophosphorylation since the triose-P transporter exchanges triose-P for $\mathrm{P}_{\mathrm{i}}$. For the situation when the rate at which triose phosphates are utilised ( $\left.T_{\mathrm{p}}\right)$ in the synthesis of carbohydrates limits $A_{\text {net }}\left(W_{\mathrm{t}}\right.$ in Eqn 2$)$, Sharkey (1985) proposed that

As there is no term dependent on $\mathrm{pO}_{2}$ in Eqn 6, there is no explicit sensitivity to low $\mathrm{pO}_{2}$ in this variant of the model. It was found that this model version might not always account for leaf gas exchange behaviour in low $\mathrm{pO}_{2}$ (Harley \& Sharkey 1991; Sage \& Sharkey 1987), promoting an updated version of the model formulation. consideration of the $\mathrm{pO}_{2}$ sensitivity of light- and $\mathrm{CO}_{2}$-saturated net $\mathrm{CO}_{2}$-assimilation capacity $\left(A_{\max }\right)$ through an 'open' photorespiratory $\mathrm{C}$ cycle. This version of the FvCB model has a $\mathrm{pO}_{2}$ sensitivity that originates indirectly from ATP consumed with metabolism of the photorespiratory product, glycolate, in the chloroplast $\left(\alpha_{\mathrm{g}}\right)$ (Fig. 1, B) as given by

203

$$
A_{\mathrm{P}}=\frac{\left(\mathrm{C}_{\mathrm{c}}-\Gamma^{*}\right) \cdot 3 T_{\mathrm{p}}}{\mathrm{C}_{\mathrm{c}}-\left(1+3 \cdot \alpha_{\mathrm{g}}\right) \cdot \Gamma^{*}}-\mathrm{R}_{\mathrm{d}}
$$
The parameter $\alpha_{\mathrm{g}}$ is multiplied by three to reflect the stoichiometry of $\mathrm{P}_{\mathrm{i}}$ consumption in oxygenation (von Caemmerer 2000; note the correct version of the equation here), and varies as a fraction between 0 and 1 depending on whether all glycolate returns to the chloroplast (a 'closed' photorespiratory cycle where C is maximally conserved, in which case Eqn 7 simplifies to Eqn 6), the return is partial, or glycolate is entirely diverted to amino acid synthesis leaving none to return (Harley \& Sharkey 1991). More than 20 years after it was proposed, this third term of the model (Eqns 6 and 7) is rarely considered in photosynthesis model fits to data (von Caemmerer 2013) and most often ignored (Kattge et al. 2009; Manter \& Kerrigan 2004; Walker et al. 2014). This is due in part to a lack of appropriate measurements (Long \& Bernacchi

This article is protected by copyright. All rights reserved. 

2003; von Caemmerer 2000) and because the evidence supporting its importance in leaves with low P concentration has been equivocal (Domingues et al. 2010). Moreover, $T_{\mathrm{p}}$ has almost never been parameterised in field situations, so it remains unclear if this

217 term needs to be considered in modelling limitations to photosynthetic $\mathrm{CO}_{2}$ assimilation (Bernacchi et al. 2013). If $T_{\mathrm{p}}$ can largely be ignored, we expect a stimulation of $A_{\text {net }}$ by low $\mathrm{pO}_{2}$ in all parts of the $\mathrm{CO}_{2}$-response curve as per Figure 2. Our field measurements

220 of plants at high and low leaf $P$ status aimed to understand if the mechanistic hypotheses of triose-P limitations to photosynthesis portrayed in Eqns 6 and 7 are consistent with field data, and if these revisions can reflect the role of $\mathrm{P}$ availability for

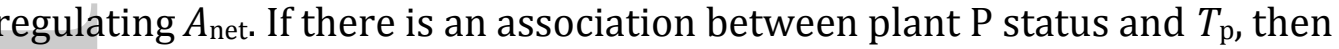
incorporation of this parameter into models may improve the predictability of $A_{\text {net, }}$ especially where rising atmospheric $\mathrm{CO}_{2}$ concentration and low soil $\mathrm{P}$ availability are

226 concerned.

\section{Research sites and plant material}

229 The research was conducted on trees and shrubs growing at five different sites in eastern and south-western Australia (Table 1), with different soil substrates and parent materials resulting in different leaf P content in their characteristic species. Sites were chosen based on known aspects of their mineralogy and previous studies on leaf nutrients (e.g., Lambers et al. 2012) so that they would provide a range in leaf total P 234 and $\mathrm{P}_{\mathrm{i}}$ fraction and thus presumably represent a range in $\mathrm{P}_{\mathrm{i}}$ limitations to $A_{\text {net }}$. Four of the five sites were infertile and low in P availability, with the fifth site on a richer soil. The Davies Park site is located at $390 \mathrm{~m}$ above sea level (a.s.l.) in the Blue Mountains in eastern Australia on thin soils overlaying Hawkesbury sandstone, a Triassic sedimentary quartzose sandstone formed over 200 Mya. The soils derived from the Hawkesbury sandstone in the Blue Mountains are shallow (5-20 cm depth) and very infertile with low P availability. The Hawkesbury Forest Experiment and adjacent Hawkesbury campus and EucFACE sites are all located at $30 \mathrm{~m}$ a.s.l. within $1 \mathrm{~km}$ of one another on Clarendon loamy sand, a deep, alluvial soil formed in the late Pleistocene by meanders of the Hawkesbury river around 1.5 Mya. The soil is a low-fertility loamy sand, with soil surface total P concentrations of $60 \mathrm{mg} \mathrm{kg}^{-1}$ soil in the upper $15 \mathrm{~cm}$ (Ellsworth et al., unpubl. data), but a large fraction of this $\mathrm{P}$ is sorbed onto aluminosilicates and ferro-manganesian silicates (Holford 1997). One of the plantations

This article is protected by copyright. All rights reserved. 
at this site (Liquidambar styraciflua L.) was horticulturally managed and had periodically-amended soil P. The Lesueur National Park site is described in detail in (Lambers et al. 2012). This site is located near Jurien Bay, WA and occurs at $80 \mathrm{~m}$ a.s.l.

250 on shallow colluvial sand and lateritic gravel over weathered sandstone from the late 251 Jurassic Yarragadee Formation (150-185 million years old; Griffin \& Burbidge 1990). 252 The sandy soil at this site is extremely low in $\mathrm{P}$, with a total $\mathrm{P}$ of $9.5 \mathrm{mg} \mathrm{kg}^{-1}$ soil in the 253 upper $30 \mathrm{~cm}$ (Lambers et al. 2012). The fifth site, Illawarra Fly in Robertson NSW, is a 254 fertile site on young soils. This site occurs at $710 \mathrm{~m}$ a.s.l. elevation on soils of the 255 Illawarra escarpment that are brown clay loams underlain by Paleocene/Pliocene basalt. These basaltic soils in the area are relatively fertile with total $\mathrm{P}$ of $1010 \mathrm{mg} \mathrm{kg}{ }^{-1}$

257 soil and frequently managed for farming, though this particular site was in a never-

258 farmed parcel of mature remnant wet sclerophyll forest. Since sites differed in 259 elevation, amounts of gases such as $\mathrm{CO}_{2}$ and $\mathrm{O}_{2}$ are reported as partial pressures (e.g., $260 \mathrm{pO}_{2}$ ) rather than mole fractions.

Whilst the focus was on measuring species of Eucalyptus as native dominants in 262 the study regions, non-Myrtaceous species were also included (Banksia spp. and 263 Persoonia levis, all Proteaceae, and Acacia oblongifolia). An exotic deciduous plantation 264 tree, Liquidambar styraciflua, was also included in the study so that inferences would not be strictly limited to native Australian sclerophyll species, which are considered to be well-adapted to low soil P (Beadle 1966).

$\mathrm{CO}_{2}$-exchange measurements

In this study, photosynthetic $\mathrm{CO}_{2}$-response curves $\left(A_{\text {net }}-\mathrm{C}_{\mathrm{i}}\right.$ response curves) were made

270 in situ on ten species of trees and shrubs at five sites in Australia (Table 1) using a

271 portable photosynthesis system (LiCor 6400XT, Licor Inc., Nebraska USA) with $6 \mathrm{~cm}^{2}$

272 chamber. All measurements were made on attached, intact leaves at the top of the crown or the outer shell of the crown when open-grown which meant accessing leaves

274 from $1 \mathrm{~m}$ up to $25 \mathrm{~m}$ high (Table 1). For tall species, access to the upper parts of the tree crowns was achieved by three different means: an articulated boom lift (Snorkel MHP13/35 Trailer Mounted Lift, Snorkel Ltd., Meadowbrook, Qld, Australia) used at the Hawkesbury site in Richmond NSW, a set of 36 m tall construction cranes (Jaso crane J4010, Jaso S.L., Idiazabal, Spain) at the nearby EucFACE site in Richmond NSW, and a custom-built steel-alloy canopy walkway going up from ground level to $30 \mathrm{~m}$ height

This article is protected by copyright. All rights reserved. 
('Illawarra fly') at Robertson, NSW. Canopy access was not necessary at the Lesueur National Park site or at Davies Park, as trees and shrubs were open-grown in each of the sclerophyll woodlands, and unshaded leaves at the outside of the crown could be readily measured.

We made field measurements of the instantaneous response of leaf net $\mathrm{CO}_{2}$ assimilation to changes in the external $\mathrm{CO}_{2}$ concentration according to Ellsworth et al. (2004), using standard coefficients recommended in Sharkey et al. (2007) when fitting the FvCB model (see below). $A_{\text {net }} C_{\mathrm{c}}$ response measurements on all species were made during the growing season in summer and autumn at seasonal temperatures and during periods of recent rainfall to reduce complications due to drought. Previous-year's leaves were measured rather than newly-emerged leaves to ensure that leaves were operating at their full photosynthetic capacity (see Denton et al. 2007; Lambers et al. 2012). The $A_{\text {net }}$ measurements were made in morning hours on sunny days so as to avoid stomatal closure and mid-day depression of $A_{\text {net. }}$.

The $A_{\text {net }}-C_{\mathrm{c}}$ response curves were started by maintaining the $\mathrm{CO}_{2}$ concentration $\left(C_{\mathrm{a}}\right)$ in the gas exchange chamber at ambient $\mathrm{CO}_{2}$ partial pressure $(\sim 38-39 \mathrm{~Pa}$ in this study) until gas-exchange rates were stable, then recording measurements. Steps for the curves were generated by decreasing $C_{\mathrm{a}}$ to near the compensation point (5 $\mathrm{Pa}$ ), and then increasing $C_{\mathrm{a}}$ stepwise across 8-9 steps (Ellsworth et al. 2012) at a constant photosynthetic photon flux density of $1800 \mu \mathrm{mol} \mathrm{m}^{-2} \mathrm{~s}^{-1}, 50-70 \%$ relative humidity, and a controlled leaf temperature (between 26 and $28^{\circ} \mathrm{C}$, depending on species). The mean leaf-air vapour pressure deficit of the measurements was $1.5 \pm 0.1 \mathrm{kPa}$. At each $C_{\mathrm{a}}$ step, we recorded $A_{\text {net, }} g_{\mathrm{s}}, C_{\mathrm{i}}$ and associated variables when stability was reached. Upon completion of measurements, leaves were placed on ice or liquid nitrogen until ready for further analysis. In the lab, leaf thickness was measured at five points on the leaf lamina using digital callipers (Mitutoyo Corp, Kawasaki, Kanagawa, Japan).

In the process of these $A_{\text {net }}-C_{\mathrm{c}}$ response measurements, at four or five of the $C_{\mathrm{a}}$ steps, we ensured that parallel measurements at ambient oxygen (21 kPa) and lowphotorespiratory oxygen $(2 \mathrm{kPa})$ were made. Low $\mathrm{pO}_{2}$ inside the gas exchange chamber was generated by routing a low- $\mathrm{O}_{2}$ tank gas (Air Liquide Australia Ltd., Melbourne, Australia) to the leaf chamber, supplied at the same slight over-pressure as for ambient air as described by Li-Cor (Li-Cor 2008) and with the excess flow to the Li-6400 pump monitored with a rotameter. A Teflon T-valve was toggled between ambient air with 21

This article is protected by copyright. All rights reserved. 

$\mathrm{kPa} \mathrm{pO}_{2}$ and $2 \mathrm{kPa}$ tank gas at the appropriate $C_{\mathrm{a}}$ steps (up to five $C_{\mathrm{a}}$ steps including at saturation). These steps were chosen in order to minimally define the initial rise to a maximum and the maximum asymptote for the $A_{\text {net }}-C_{\mathrm{c}}$ curve at low $\mathrm{pO}_{2}$, given that the

316 shape of these curves has long been known (Laing et al. 1974; von Caemmerer 2000). The flow excess was maintained around $0.3 \mathrm{~L} \mathrm{~min}^{-1}$. Measurements of $A_{\text {net }}$ in $2 \mathrm{kPa} \mathrm{pO}_{2}$ were completely reversible as described in Laing et al. (1974)(see Supporting Information, Fig. S1).

Calculations of $\mathrm{O}_{2}$ corrections and mesophyll conductance to $\mathrm{CO}_{2}$ We used three corrections for changes in $\mathrm{pO}_{2}$ in the carrier-gas in the LI-6400XT photosynthesis system that originated from the change in density due to different gas concentrations. The corrections employed were: i) increased air-flow rate through the $\mathrm{CO}_{2}$-injector system due to reduced air viscosity with decreased $\mathrm{pO}_{2}$, ii) band broadening of $\mathrm{CO}_{2}$ infrared absorption (Burch et al. 1962) incorporated into the standard Li-6400 software, and iii) band broadening of water vapour infrared absorption (Bunce 2002).

Given theoretical issues raised by Gu \& Sun (2014) concerning the dependence of mesophyll conductance to $\mathrm{CO}_{2}\left(g_{\mathrm{m}}\right)$ on $C_{\mathrm{i}}$, we assumed a constant $g_{\mathrm{m}}$ for different $C_{\mathrm{i}}$ steps in the response-curve data. Mesophyll conductance was either measured or estimated for each species for calculations of $C_{\mathrm{c}}$. For three species amongst those in Table 1 ranging in $A_{\text {net }}$ from highest and lowest, we measured instantaneous $g_{\mathrm{m}}$ with online carbon-isotope discrimination using tunable diode laser absorption spectroscopy (TDLAS; Campbell Scientific TGA100A, Logan, UT, USA). Our $g_{\mathrm{m}}$ calculations follow Tazoe et al. (2011) with further description in Crous et al. (2013). We then estimated mean $g_{\mathrm{m}}$ of all the species using a relationship for $g_{\mathrm{m}}$ as a function of $g_{\mathrm{s}}$ from our measurements $\left(g_{\mathrm{m}}=-0.04+1.34^{*} g_{\mathrm{s}}, \mathrm{r}^{2}=0.54\right.$; Supporting Information Fig. S2). In a review of available data, $g_{\mathrm{m}}$ usually scaled with $g_{\mathrm{s}}$ especially amongst well-watered plants (Flexas et al. 2012). After incorporating $g_{\mathrm{m}}$, we derived biochemical model parameters using the $A_{\text {net }}-C_{\mathrm{c}}$ data.

Photosynthetic parameter fits were done in R (Team 2014) using kinetic coefficients in Sharkey et al. (2007) to standardise the fits across species, but using $\Gamma^{*}$ and its temperature dependence specifically measured for Eucalyptus (Crous et al. 2013). We fit $V_{\text {cmax }}, J_{\max }$ and $T_{\mathrm{p}}$ piece-wise using specified ranges of conditions where

This article is protected by copyright. All rights reserved. 

each parameter was judged to limit $A_{\text {net }}$ following guidelines in Sharkey et al. (2007) with the nonlinear solutions generated using the 'optim' package in R. $T_{\mathrm{p}}$ was fit for $A_{\text {net }}$ when $C_{\mathrm{c}}>40 \mathrm{~Pa}$ and $\mathrm{pO}_{2}$ of $2 \mathrm{kPa}$. As a more robust fitting approach with fewer assumptions, we also pooled data for all leaves within a species and simultaneously solved for species-level $V_{\text {cmax }}, J_{\max }$ and $T_{\mathrm{p}}$ at both $\mathrm{pO}_{2}$ levels using the 'nls' package in $\mathrm{R}$. Across species, the two sets of solutions agreed well with one another, since slopes for each parameter were close to unity (slopes of $0.981,0.966$ and 0.840 for $V_{\text {cmax }}, J_{\max }$ and $T_{\mathrm{p}}$, respectively, estimated for piecewise compared with simultaneously-solved). $V_{\text {omax }}$ the maximum velocity of oxygenase activity, was fit to the data from both $\mathrm{pO}_{2}$ levels for low $C_{\mathrm{c}}$ where oxygenase activity of Rubisco is considered limiting, following equations in Farquhar et al. (1980).

\section{Leaf chemical analyses}

After measurements, leaves were immediately placed on ice and transported to the laboratory, where thickness and area were measured on a subsample, whilst the remainder was frozen and subsequently dried to a constant mass at $70^{\circ} \mathrm{C}$. The leaf lamina dry mass per unit area $\left(M_{\mathrm{a}}\right)$ was calculated from the ratio of dry mass to fresh area. The dried sample was ground finely in a ball mill, and used for analyses of total $\mathrm{N}$ concentration, total $\mathrm{P}$ concentration, inorganic $\mathrm{P}\left(\mathrm{P}_{\mathrm{i}}\right)$ concentration, and starch and soluble sugar concentrations. Leaf $\mathrm{N}$ concentration was analysed by elemental analysis 366 after combustion using a CHN elemental analyser (TruSpec micro, LECO Corp., St. Joseph, MI, USA; or FLASH EA 1112 Series CHN analyser, Thermo-Finnigan, Waltham, MA USA). Leaf total P concentrations were measured after digesting dried leaf tissue with concentrated sulfuric acid $\left(\mathrm{H}_{2} \mathrm{SO}_{4}\right)$ and hydrogen peroxide $\left(\mathrm{H}_{2} \mathrm{O}_{2}\right)$ in a microwave digester apparatus (Berghof speedwave four, Berghof Products GmbH, Eningen, Germany). The solutions containing total $\mathrm{P}$ or the $\mathrm{P}_{\mathrm{i}}$ fraction were analysed colourimetrically at $880 \mathrm{~nm}$ (AQ2, SEAL Analytical, Ltd., Milwaukee, WI USA) after a standard molybdate reaction (Close \& Beadle 2004). Analyses of N and P concentrations

375 and $\mathrm{P}$ content $\left(\mathrm{mmol} \mathrm{m}^{-2}\right)$ in this manuscript due to differences in leaf thickness 376 amongst the species (Table 1). Bulk leaf $\mathrm{P}_{\mathrm{i}}$ was determined by extracting samples in 0.3 $377 \mathrm{M}$ TCA at $4^{\circ} \mathrm{C}$ before cold centrifuging at $9224 \times \mathrm{g}(10,000 \mathrm{rpm})$ for $5 \mathrm{~min}$ and collecting 

the filtrate (Close \& Beadle 2004). The $\mathrm{P}_{\mathrm{i}}$ concentrations in the samples were determined against standards made with $\mathrm{KH}_{2} \mathrm{PO}_{4}$ in serial dilution.

\section{RESULTS}

The set of species used in this study ranged two-fold in their leaf thickness, and nearly ten-fold in their leaf P content (Table 1). $A_{\text {net }}$ varied more than two-fold, between 10 and $26 \mu \mathrm{mol} \mathrm{m}{ }^{-2} \mathrm{~s}^{-1}$ among the species when measured at $C_{\mathrm{i}}$ between 27-28 Pa. As a stoichiometric index of $\mathrm{P}$ versus $\mathrm{N}$ limitation, six of the ten species studied had $\mathrm{N}: \mathrm{P}$ ratios $>20$, while E. fastigata and L. styraciflua, both from moderately-fertile conditions, had N:P of 10-13 (see Supporting Information, Table S1).

Biochemical modelling from $A_{\text {net }}-C_{\mathrm{c}}$ response curves at both 21 and $2 \mathrm{kPa} \mathrm{pO}$ using the classic FvCB model would suggest a slightly higher $A_{\text {net }}$ asymptote at high $C_{\mathrm{c}}$ and low $\mathrm{pO}_{2}$ (i.e. similar $A_{\max }$ at ambient and low $\mathrm{pO}_{2}$ ) due to the lower $\Gamma^{*}$ as per Eqn 5 above (Fig. 2). Thus, a stimulation of $A_{\text {net }}$ by low $\mathrm{pO}_{2}$ was expected both in the carboxylation-limited region of the $\mathrm{CO}_{2}$-response curve and, though smaller, also in the RuBP-regeneration-limited region or where $A_{\text {net }}$ is saturated with respect to $C_{\mathrm{a}}$. Consistent with this, there was an average of $23 \%$ stimulation in $A_{\text {net }}$ at ambient $\mathrm{CO}_{2}$ under low-photorespiratory conditions using $2 \mathrm{kPa} \mathrm{pO}_{2}$ in the carboxylation-limited region of the $A_{\text {net }}-C_{\mathrm{c}}$ response curve (Fig. 3 and data not shown). However, in contrast to theoretical expectations, none of the ten species measured showed the expected small $A_{\text {net }}$ stimulation in the RuBP-regeneration-limited region in $2 \mathrm{kPa} \mathrm{pO}_{2} \mathrm{compared}$ with $A_{\text {net }}$ in normal $\mathrm{pO}_{2}$. Rather, species either showed similar $A_{\max }$ values as asymptotes to the $A_{\text {net }}-C_{\mathrm{c}}$ response in $2 \mathrm{kPa} \mathrm{pO} \mathrm{O}_{2}$ compared with $21 \mathrm{kPa} \mathrm{pO} \mathrm{O}_{2}$ (Fig. $3 \mathrm{~A}, \mathrm{~B}$ ), or a dramatic reverse response for the $A_{\max }$ in 2 versus $21 \mathrm{kPa} \mathrm{pO} 2$ (Fig. 3C,D), with about a $20 \%$ reduction in $A_{\max }$ at $2 \mathrm{kPa} \mathrm{pO}_{2}$ compared with normal $\mathrm{pO}_{2}$. The cross-over between curves at normal and low $\mathrm{pO}_{2}$ occurred at $C_{\mathrm{i}}$ values as low as $28 \mathrm{~Pa}$, up to $40 \mathrm{~Pa}$ depending on species. In low $\mathrm{pO}_{2}$ there was also a sharp transition between Rubiscolimited photosynthesis at low $C_{\mathrm{c}}$ and RuBP-regeneration and $T_{\mathrm{p}}$ limited photosynthesis compared to normal $\mathrm{pO}_{2}$ (Fig. 3). For our study species, the difference in $A_{\max }$ between normal and low $\mathrm{pO}_{2}$ was between 2 and $14 \mu \mathrm{mol} \mathrm{m}{ }^{-2} \mathrm{~s}^{-1}$ (average of $5.8 \mu \mathrm{mol} \mathrm{m}^{-2} \mathrm{~s}^{-1}$ ), with low $\mathrm{pO}_{2}$ values consistently lower. This was significantly different from zero for all species, even for B. attenuata $(P=0.017$ in a one-tailed t-test $)$ and $P$. levis $(P=0.01)$, both of which had rather small mean differences in asymptotic $A_{\text {net }}$ between normal and low 
$\mathrm{pO}_{2}$ of about $2 \mu \mathrm{mol} \mathrm{m} \mathrm{m}^{-2} \mathrm{~s}^{-1}$ (Fig. 3A,B). This result establishes that there was a reverse sensitivity of $A_{\text {net }}$ to the reduction in $\mathrm{pO}_{2}$ at high $C_{\mathrm{c}}$ across the range of species measured in the field. Given that this reverse sensitivity in low $\mathrm{pO}_{2}$ conditions was significant in all species, we considered it valid to use the model of Harley \& Sharkey (1991) to estimate the P limitation component of the biochemical model, rather than the simpler model of Sharkey (1985) that has been recommended to standardise model fitting.

Estimates of $V_{\text {cmax }}$ from independent gas-exchange measurements at either $\mathrm{pO}_{2}$ level were similar (Fig. 4A). However, we could not recover the same $A_{\max }$ in different $\mathrm{pO}_{2}$ levels using the traditional two-parameter FvCB photosynthesis model (Fig. 4B). The $A_{\max }$ estimated in low $\mathrm{pO}_{2}$ was lower than expected based on $A_{\max }$ in normal $\mathrm{pO}_{2}$ (under the 1:1 line in Fig. 4B). The largest $A_{\max }$ reductions in low $\mathrm{pO}_{2}$ were in species with high $A_{\max }$ at normal $\mathrm{pO}_{2}$, such as E. fastigata and L. styraciflua (average of 8 and 12 $\mu \mathrm{mol} \mathrm{m}{ }^{-2} \mathrm{~s}^{-1}$ lower, respectively). This was further evidence that an additional parameter to the $\mathrm{FvCB}$ photosynthesis model was needed to fit photosynthesis to our field measurements. The difference in modelled $A_{\max }$ using the traditional FvCB model to the $A_{\max }$ predicted by the model revision proposed by Harley \& Sharkey (1991) was largest for species with high $A_{\max }$ in normal air ( $21 \mathrm{kPa} \mathrm{pO}_{2}$; Fig. 4C). Fitting the $T_{\mathrm{p}}$ parameter using Eqn 7 proposed by Harley \& Sharkey (1991) to the data, we were able to recover the $A_{\max }$ that we had measured in low $\mathrm{pO}_{2}$ (Fig. 4D). Taken together, all species showed a reduced $A_{\max }$ at low $\mathrm{pO}_{2}$, with the largest reductions occurring in species with the highest $A_{\max }$. These reductions were recovered once the $T_{\mathrm{p}}$ parameter (Eqn 7) was employed in the model fits.

The difference in $A_{\max }$ for the model without $T_{\mathrm{p}}$ considered versus the model with $T_{\mathrm{p}}$ considered was positively correlated with leaf $\mathrm{P}_{\mathrm{i}}$ content up to a threshold of about 2 $\mathrm{mmol} \mathrm{P}_{\mathrm{i}} \mathrm{m}^{-2}\left(\mathrm{r}^{2}=0.4, \mathrm{P}<0.0001\right)$, beyond which there was no apparent relationship (Fig. 5). There was a similar but weaker relationship $\left(\mathrm{r}^{2}=0.2\right)$ for total $T_{\mathrm{p}}$ below a threshold of $\sim 10 \mathrm{mmol} \mathrm{P} \mathrm{m}^{-2}$ (not shown). $T_{\mathrm{p}}$ was itself only very weakly correlated with leaf $\mathrm{P}_{\mathrm{i}}$ content up to a threshold of $2 \mathrm{mmol} \mathrm{P}_{\mathrm{i}} \mathrm{m}^{-2}\left(\mathrm{r}^{2}=0.10, \mathrm{P}<0.01\right.$; data not shown). Six species (A. oblongifolia, B. attenuata, B. serrata, E. todtiana, E. tereticornis and $P$. levis) all had leaf $P_{i}$ contents in the linear region, where the magnitude of suppression of $\mathrm{CO}_{2}$-saturated photosynthesis by low $\mathrm{pO}_{2}$ varied strongly with $\mathrm{P}_{\mathrm{i}}$. $E$. fastigata and L. styraciflua both had high leaf $\mathrm{P}_{\mathrm{i}}$ contents and high $A_{\max }$ differences, falling in the saturating region of Fig. 5. The amount of total leaf $\mathrm{P}$ present as $\mathrm{P}_{\mathrm{i}}$ averaged

This article is protected by copyright. All rights reserved. 
$30 \pm 2 \%$ (mean \pm s.e.) among the species in our study. Liquidambar styraciflua had the highest free $P_{i}$ in leaves, at $46 \pm 4 \%$ of total leaf $P$ concentration. B. attenuata, B. serrata and P. levis had the lowest total leaf P concentrations (around $0.35 \mathrm{mg} \mathrm{P} \mathrm{g-1;}$; Table S1), but similar $\mathrm{P}_{\mathrm{i}}$ fractions as the species average above.

For the set of ten species across a range in soils and P supply levels, the individual photosynthetic model components $V_{\text {cmax }}, J_{\max }$, and $T_{\mathrm{p}}$ were all correlated with leaf chemical traits, though correlations with total leaf $\mathrm{P}_{\text {area }}$ were strongest (Table 2, Fig. 6). The three species from Davies Park in the Blue Mountains of NSW had the lowest leaf Parea closely followed by those from Lesueur National Park in Western Australia. The strongest relationship between the biochemical components of leaf photosynthetic capacity and leaf chemistry was between $J_{\max }$ and leaf $\mathrm{P}_{\text {area }}\left(\mathrm{R}^{2}=0.66\right.$, Fig. 6c). Bivariate relationships between photosynthetic model components and leaf $\mathrm{N}_{\text {area }}$ were not significant $\left(P>0.10\right.$, Table 2), nor was $A_{\max }$ associated with leaf $\mathrm{N}_{\text {area }}$ across the set of species. There were no significant relationships between any of these traits and $\mathrm{M}_{\mathrm{a}}$. $V_{\text {omax }}$ was not significantly correlated with $\mathrm{N}_{\text {areaa }}$ and was only marginally significantly correlated with $P_{\text {area }}\left(P=0.052\right.$; Table 2 and Fig. 6b). $V_{\text {omax }}$ fit to data at both measurement $\mathrm{pO}_{2}$ levels was significantly correlated with $V_{\text {cmax }}$ fit to measurements at both $\mathrm{pO}_{2}(P=0.0052$; not shown $)$ with a slope of 0.17 and a significant $y$-intercept.

\section{DISCUSSION}

Reductions in $A_{\max }$ during exposure to low $\mathrm{pO}_{2}$ have been documented for over 50 years (Joliffe \& Tregunna 1968), but have rarely been measured in the field. Despite suppression of photorespiration by low $\mathrm{pO}_{2}$ at the current atmospheric $C_{\mathrm{a}}$ (Fig. 2), we have shown that $A_{\text {net }}$ at high $C_{\mathrm{i}}$ and low $\mathrm{pO}_{2}$ is reduced, rather than higher as would be expected from theory based on the biochemical regulation of photosynthesis (Farquhar et al. 1980; Laing et al. 1974; von Caemmerer \& Farquhar 1981). All ten tree and shrub species studied at a range of Australian sites showed this response to varying degrees, at moderate summertime temperatures (Fig. 4). According to the Harley \& Sharkey (1991) theoretical model, when leaves operate at near-saturating $C_{\mathrm{i}}$, photorespiratory glycerate may not completely re-enter the PCR cycle, so that $\mathrm{P}_{\mathrm{i}}$ released by phosphoglycolate phosphatase in the chloroplast, that would normally have been used by the glycerate kinase reaction upon photorespiratory $\mathrm{C}$ return to the chloroplast, is instead

This article is protected by copyright. All rights reserved. 

available in the stroma for RuBP regeneration (Fig. 1, B). Under low-photorespiratory conditions, this additional source of $\mathrm{P}_{\mathrm{i}}$ becomes unavailable, resulting in slower RuBP regeneration and lower $A_{\max }$ at low $\mathrm{pO}_{2}$ than at normal $\mathrm{pO}_{2}$. Modelling using the

478 equation for $T_{\mathrm{p}}$ in Harley \& Sharkey (1991) gives $A_{\max }$ results that are broadly consistent with our data (Fig. 4). While limitations to photosynthesis by triose-P utilisation are considered to be uncommon and are often ignored in photosynthetic model-fitting, our field measurements under low-photorespiratory conditions show that $T_{\mathrm{p}}$ can be limiting $A_{\text {max }}$ in a wide range of woody species.

An alternative hypothesis for $T_{\mathrm{p}}$ limitations to $A_{\max }$ suggests that excessive synthesis of triose-P to be exported from the chloroplast increases recycling of $\mathrm{P}_{\mathrm{i}}$ entering chloroplasts, with higher stromal $P_{i}$ leading to the accumulation of 3PGA and decreasing phosphoglucoisomerase activity and suppressing starch synthesis (Sharkey 1985; Stitt et al. 2010; Fig. 1, A). While simpler in concept and in formulation (Eqn 6), the $T_{\mathrm{p}}$ limitation emerging from conservative $\mathrm{C}$ cycling back to the chloroplast cannot explain what we found here, because it describes $\mathrm{pO}_{2}$-insensitive photosynthesis, whilst we found a strong reverse sensitivity of $A_{\max }$ to low $\mathrm{pO}_{2}$ which is only predicted by the Harley \& Sharkey (1991) model of $T_{\mathrm{p}}$ limitation. Previous treatments using the Sharkey (1985) formulation did not conduct measurements at low $\mathrm{pO}_{2}$ at a range of $C_{\mathrm{a}}$ levels, and thus have not been able to distinguish between $\mathrm{pO}_{2}$-insensitive and reversesensitive photosynthesis. On the basis of the Harley \& Sharkey (1991) model, our data provide strong evidence that not only is photorespiration a source of amino acids through $\mathrm{NH}_{3}$ release in glycine metabolism (Wingler et al. 2000), but also that glycolate diversion from reentry into the chloroplast during photorespiration simultaneously frees stromal $\mathrm{P}_{\mathrm{i}}$ to permit enhanced photophosphorylation and RuBP regeneration, thus permitting high $A_{\text {max. }}$. Measurements of this phenomenon on a much broader set of $\mathrm{C}_{3}$ plant species is needed to understand the generality of this phenomenon, but the set of species we studied represents a range of phylogenies and includes species with different affinities for growing on low-P sites. All these species showed significant decreases in $A_{\max }$ measured during transient non-photorespiratory conditions. The decreases in $A_{\max }$ in low $\mathrm{pO}_{2}$ for L. styraciflua, E. fastigata and E. dunnii were all greater than $5 \mu \mathrm{mol} \mathrm{m}^{-2} \mathrm{~s}^{-1}$ and as high as $12 \mu \mathrm{mol} \mathrm{m}^{-2} \mathrm{~s}^{-1}$ (in E. fastigata), and thus were much larger than those of the order of $2 \mu \mathrm{mol} \mathrm{m}^{-2} \mathrm{~s}^{-1}$ shown for soybean in Harley \& Sharkey (1991). Therefore,

This article is protected by copyright. All rights reserved. 

we suggest that this phenomenon may be common amongst a number of plant genera, and potentially across a significant geographic expanse. There is a need for broader consideration of this mechanism among species, as currently $T_{\mathrm{p}}$ limitations to $A_{\max }$ are

511 ascribed to the parameter $J_{\max }$ in a large number of studies (for example, Kattge et al. 2009; Manter \& Kerrigan 2004; Walker et al. 2014). We also suggest that the mechanism proposed by Harley \& Sharkey (1991) is more properly called phosphate limitation rather than triose-P limitation, since triose-P is not necessarily integral to the proposed mechanism (see Fig. 1, B). Nevertheless, we have retained the terminology of Harley \& Sharkey (1991) in fitting Eqn 7, but suggest that $T_{\mathrm{p}}$ can be more broadly considered as phosphate limitation to $A_{\text {net }}$.

Internal recycling of $\mathrm{P}_{\mathrm{i}}$ in cells is important for the balanced production of ATP and regeneration of RuBP as essential requirements for high $\mathrm{CO}_{2}$-assimilation rates.

520 While a source for $\mathrm{P}_{\mathrm{i}}$ for photophosphorylation to regenerate RuBP as depicted in Fig. 1 (see B in Fig. 1) could be a valuable mechanism for sustaining $A_{\text {net }}$ at high $C_{\mathrm{i}}$ in plants in conditions with limiting soil $\mathrm{P}$, our measurements do not suggest this occurs at the extremely low P levels characterising both the Lesueur National Park and Davies Park sites. Among the ten woody species we measured including some on infertile sites with low soil P-availabilities, plants with low leaf $\mathrm{P}$ concentrations (total leaf $\mathrm{P}<400 \mu \mathrm{g} \mathrm{g}$-1, for instance) also had slow rates of photorespiration and an apparent high fractional return of photorespiratory glycerate to the chloroplast, resulting in a relatively small inhibition of $A_{\max }$ in low $\mathrm{pO}_{2}$ and high $C_{\mathrm{i}}$ (Fig. 3a,b). However, our findings are consistent with the previously-overlooked mechanism of glycerate sequestration during photorespiration may in fact be common in a number of woody species. This mechanism operates at high $C_{\mathrm{i}}$ (but to $C_{\mathrm{i}}$ as low as $28 \mathrm{~Pa}$ depending on species; Fig. 3) which means that it is relevant for a substantial fraction of canopy leaves maintained in shade where RuBP regeneration and triose-P supplies may limit $A_{\text {net. }}$ It may also be relevant in elevated atmospheric $\mathrm{CO}_{2}$ concentrations (Campbell \& Sage 2006) with a role in increasing the degree of cellular $\mathrm{P}_{\mathrm{i}}$-deficiency with decreased photorespiration, expected as $C_{\mathrm{a}}$ increases in the future. The mechanism hypothesised by Harley \& Sharkey (1991) and supported by our data is not yet considered in physiologicallybased models used to project plant $\mathrm{CO}_{2}$ assimilation behaviour into the future (Wang et al. 2010). Our identification of this mechanism in the field opens an important new area of research relevant to expected future conditions including elevated $\left[\mathrm{CO}_{2}\right]$, and further

This article is protected by copyright. All rights reserved. 
field measurements of this sort are crucial to help resolve the range of ecological contexts where $\mathrm{P}_{\mathrm{i}}$ regulation over $A_{\max }$ may be most important.

544 Eqn 7 and shown in Fig. 1 requires glycolate exported from the chloroplast to be sequestered, metabolised or exported from the cell, rather than being converted into glycerate for re-entry into the chloroplast. What are the possible mechanisms for this $\mathrm{C}$ "diversion" rather than conservation by chloroplast re-entry? Harley \& Sharkey (1991) cited ${ }^{14} \mathrm{C}$ labelling evidence to suggest photorespiratory $\mathrm{C}$ export by the vascular system to other parts of the plant (Wingler et al. 2000), and at least $12 \%$ of the amino acid composition of phloem in Eucalyptus comprises serine and glycine (Merchant et al. 2010), demonstrating that this export is plausible. There are other plausible fates for this $\mathrm{C}$ that may also be important (Reumann \& Weber 2006). Glycolate and glyoxylate 553 products of photorespiration (Fig. 1; Wingler et al. 2000) can be oxidised by glycolate oxidase in the peroxisome to form oxalic acid, which is stored in vacuoles or metabolised to calcium oxalate crystals, common in a wide range of plants (Franceschi \& Nakata 2005) and documented for both Eucalyptus and Acacia (Brown et al. 2013). Alternatively, oxalate might be metabolised again (Havrir 1984) and allow glycerate reentry into the chloroplast when the requirement for $\mathrm{P}_{\mathrm{i}}$ is less. Glycine participates in the early steps of porphyrin synthesis in the mitochondria as part of chlorophyll assembly (Beale 1978) as well as in the synthesis of glutathione, which is involved in stress protection (Wingler et al. 2000). Whilst the ultimate fate of photorespiratory glycolate may vary amongst different plant species, evidence of multiple mechanisms driving a lack of $\mathrm{C}$ return to the chloroplast after photorespiratory metabolism provides support for the sequestration of glycolate or its products after photorespiration, a key part of the hypothesised mechanism of Harley \& Sharkey (1991).

Some implications of the incomplete photorespiratory glycerate re-entry and subsequent extra available $\mathrm{P}_{\mathrm{i}}$ (see B in Fig. 1) are that species with low photorespiration such as Proteaceae (B. attenuata, B. serrata, P. levis; see Supporting Information, Table S1) would have a low flux rate of chloroplastic $P_{i}$ made available by this mechanism compared with species with higher photorespiration. Some Proteaceae species also allocate more $\mathrm{P}$ to their mesophyll cells rather than their epidermal cells (Lambers et al. 572 2015), compared with other dicots that have relatively high P levels in epidermal cells 573 (Conn \& Gilliham 2010). Indeed, five species in our study (B. attenuata, B. serrata, E.

This article is protected by copyright. All rights reserved. 

todtiana, E. tereticornis and P. levis) all have a leaf $\mathrm{P}_{\mathrm{i}}$ content where the magnitude of suppression of $A_{\max }$ by low $\mathrm{pO}_{2}$ varies strongly with $\mathrm{P}_{\mathrm{i}}\left(\mathrm{P}_{\mathrm{i}}<2 \mathrm{mmol} \mathrm{m}^{-2}\right.$, Fig. 5). This suggests that at low leaf $\mathrm{P}$ contents, these species must rely on existing stromal $\mathrm{P}_{\mathrm{i}}$ pools,

577 rather than those saved by the lack of glycerate re-entry during photorespiration at high

$578 C_{\mathrm{i}}$. Lambers et al. (2012) showed that photosynthetic cells of mature Banksia leaves 579 extensively replace phospholipids by lipids that do not contain P, i.e. galactolipids and sulfolipids, which reduces their demand for $\mathrm{P}_{\mathrm{i}}$ for lipid synthesis and hence increases $\mathrm{P}_{\mathrm{i}}$ available for participation in photosynthetic carbon metabolism. Moreover, these species also operate at very low levels of ribosomal RNA (Sulpice et al. 2014), which is a major fraction of leaf $\mathrm{P}$ (Veneklaas et al. 2012). Mechanisms for internal P conservation such as these may obviate the need for P contributed from the lack of photorespiratory glycerate re-entry mechanism in P-impoverished ecosystems. showed the fastest RuBP regeneration rates (i.e. high $J_{\max }$ ), the highest leaf $\mathrm{P}_{\mathrm{i}}$ contents, and also showed the largest decreases in $A_{\max }$ at low $\mathrm{pO}_{2}$. Why do these fast-metabolism plants show an apparently large $T_{\mathrm{p}}$ limitation of $A_{\max }$, when they also have high $\mathrm{P}_{\mathrm{i}}$ ? The bulk leaf $\mathrm{P}_{\mathrm{i}}$ measurements are indicative but inconclusive as only the chloroplastic $\mathrm{P}_{\mathrm{i}}$ fraction is relevant to the hypothesised mechanism. The reverse sensitivity to $\mathrm{pO}_{2}$ at high $C_{\mathrm{c}}$ can occur in species with high photosynthetic activity where the requirement for $P_{i}$ for ATP synthesis is balanced against the need to maintain low $P_{i}$ for starch and sucrose synthesis (Sharkey \& Vassey 1989). With rapid triose-P production in photosynthesis exceeding the capacity to use triose-P in such species, low $\mathrm{pO}_{2}$ would decrease photorespiration and reduce $\mathrm{P}_{\mathrm{i}}$ from dephosphorylation of phosphoglycolate as well as greatly reduce carbon leaving the Calvin-Benson cycle by serine and/or glycine export. It is not clear yet if these two mechanisms are mutually exclusive, but they are consistent with the data in Figure 5. There is an additional possibility that the $T_{\mathrm{p}}$ limitation of species with high $A_{\max }$ may occur due to the high P requirements in such species for ribosomal RNA (rRNA), which is needed to support rapid rates of protein synthesis and growth (Matzek \& Vitousek 2009; Niklas et al. 2005). The P contained in RNA, particularly rRNA, is a significant fraction of the total non-vacuolar $P$ in leaves (Raven 2012). Hence, if high $P$ costs of rRNA for protein turnover are necessary to support rapid photosynthesis in mature leaves as suggested by Veneklaas et al. (2012) and others (Matzek \& Vitousek

This article is protected by copyright. All rights reserved. 
2009), then this protein synthesis may be achieved from two concurrent photorespiratory products. Amino acids are generated from photorespiratory ammonia $\left(\mathrm{NH}_{3}\right)$ release in glycine decarboxylation (Wingler et al. 2000), and the lack of photorespiratory glycerate re-entering the chloroplast frees chloroplastic ATP for enhancing RuBP regeneration and increasing $A_{\max }$, while also freeing $\mathrm{P}_{\mathrm{i}}$ for P-rich ribosomes to generate proteins in the stroma (Fig. 1). How much glycine or serine is directed away from the photorespiratory pathway and chloroplast re-entry and rather used for protein biosynthesis is unclear. However, the release of $\mathrm{N}$ from photorespiration may be as large as from nitrate reduction (Wingler et al. 2000), and hence the release of ATP for RuBP regeneration may also be large (Fig. 3B,D). There is supporting evidence as one of the slow-growing species in our study, Banksia attenuata, with low photorespiration (Fig. 3C) was recently demonstrated to have low rRNA concentrations in mature leaves at the Lesueur site (Sulpice et al. 2014). We believe that the hypothesis of both $\mathrm{N}$ and $\mathrm{P}$ release in photorespiration establishes new significance for what has previously been considered to be a "wasteful" process (Busch 2013; Ogren 1984; Wingler et al. 2000), but it also requires further investigation. There has been considerable interest in the role of $\mathrm{P}$ in limiting photosynthesis and whether $\mathrm{P}$ can directly influence leaf photosynthetic capacity (Reich et al. 2009). The relationships between biochemical parameters underlying photosynthetic capacity and leaf $\mathrm{P}$ content in Fig. 6 across a range in P supply argue for a stronger and more direct role for P in 7 regulating $A_{\max }$ in this set of species than for N. Our data have provided evidence of a direct role of $\mathrm{P}$ in leaf photosynthetic capacity that is likely not currently realised much since current $C_{\mathrm{i}}$ is often lower than $\sim 28 \mathrm{~Pa}$, but could become important with rising $C_{\mathrm{a}}$. Though the nature and biochemistry of $T_{\mathrm{p}}$ limitations to $A_{\max }$ are not fully elucidated, when leaf $\mathrm{P}$ concentrations are moderate it appears that the extra photorespiratory source of $\mathrm{P}_{\mathrm{i}}$ derived from a net $\mathrm{C}$ export from the chloroplast can help sustain rapid rates of $A_{\text {max. }}$

\section{CONCLUSIONS}

While triose-P utilisation $\left(T_{\mathrm{p}}\right)$ limitations to photosynthesis are considered to be uncommon and are often ignored in photosynthetic model-fitting, we have shown that

$T_{\mathrm{p}}$ can be limiting in a wide range of species from across soil P gradients in the field, with short-term high $\mathrm{C}_{\mathrm{i}}$. Hence, what are actually $T_{\mathrm{p}}$ limitations judged from

This article is protected by copyright. All rights reserved. 

measurements at low $\mathrm{pO}_{2}$, are currently attributed to $J_{\max }$ limitations in the two-phase FvCB model that is frequently fit to measurements at normal $\mathrm{pO}_{2}$. The results suggest that $\mathrm{pO}_{2}$ manipulation in measurements of $A_{\text {net }}$ can lead to insights into $\mathrm{P}_{\mathrm{i}}$ limitations to

$642 A_{\text {net }}$ both in the present and in a future with elevated atmospheric $\mathrm{CO}_{2}$ leading to 643 reduced photorespiration. Intracellular $P_{i}$ release from photorespiration is inhibited at 644 low $\mathrm{pO}_{2}$, reducing $A_{\max }$ in all species, but to varying extent depending on their available $645 \mathrm{P}_{\mathrm{i}}$ pools. Species with largest photosynthetic capacity and highest $\mathrm{P}_{\mathrm{i}}$ contents apparently 646 rely most on ATP made available from photorespiration. Hence, this mechanism is most 647 important in fast-growing species at moderate P levels and with high photosynthetic capacity, rather than species growing in P-impoverished soils. The mechanism we have 649 identified should be further explored, but is expected to contribute to the economy of $\mathrm{P}$ 650 for plants in tropical or subtropical rainforest vegetation as well as in Mediterranean 651 vegetation on soils with moderate to low P availability, but not in those species that 652 deploy alternative mechanisms to function at very low leaf [P]. Phosphate limitations to 653 photosynthetic capacity are likely more common in the field than previously thought,

654 and likely contribute to improving the predictability of $\mathrm{CO}_{2}$-assimilation rates in such 655 instances. It is recommended that those interested in modelling how biochemistry 656 regulates $A_{\text {net }}$ should consider the role of photorespiration and employ three limitations 657 in the biochemical model of photosynthesis with the possibility of glycerate not reentering the Calvin-Benson cycle.

\section{ACKNOWLEDGEMENTS}

This research was supported by the Australian Research Council (ARC Discovery grant DP110105102 to DSE and DP110101120 to HL). Data from this study is stored at Research Data Australia (doi: tobedetermined). We are grateful to O.K. Atkin (ANU), K. Bloomfield (Leeds University), and P. Milham (NSW government) for advice concerning the chemical analysis of $\mathrm{P}_{\mathrm{i}}$ and total $\mathrm{P}$ in leaves. S. Wohl expertly operated the cranes for canopy access at EucFACE. We thank the Blue Mountains City Council (BMCC) and particularly Michael Hensen, for permission to sample at Davies Park in the Blue 667 Mountains, NSW, the staff at the Illawarra Fly for providing access to the canopy walkway in Robertson, NSW, and the Western Australia Department of Parks and Wildlife for sampling access to Lesueur National Park, WA. Further, we thank Prof. Tom 
671 draft. A portion of this work was conducted at the EucFACE facility, an initiative of the 672 Australian Government's economic stimulus package and part of Australia's national 673 collaborative research infrastructure (NCRIS).
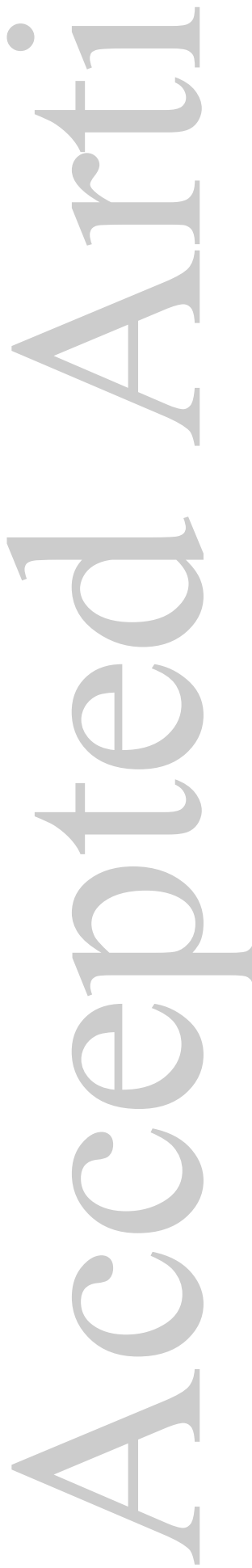

This article is protected by copyright. All rights reserved. 


\section{REFERENCES}

676 Aerts R. \& Chapin F.S. (2000) The mineral nutrition of wild plants revisited: a re677 evaluation of processes and patterns. Advances in Ecological Research, 30, 1-67. 678 Archontoulis S.V., Yin X., Vos J., Danalotos N.G. \& Struick P.G. (2012) Leaf photosynthesis

679

680

681

682

683

684

685

686

687

688

689

690

691

692

693

694

695

696

697 and respiration of three bioenergy crops in relation to temperature and leaf nitrogen: how conserved are biochemical model parameters among crop species? Journal of Experimental Botany, 63, 895-911.

Beadle N.C.W. (1966) Soil phosphate and its role in molding segments of the Australian flora and vegetation, with special reference to xeromorphy and sclerophylly. Ecology, 47, 992-1007.

Beale S.I. (1978) Delta-aminolevulinic acid in plants - its biosynthesis, regulation, and role in plastid development. Annual Review of Plant Physiology and Plant Molecular Biology, 29, 95-120.

Bernacchi C.J., Bagley J.E., Serbin S.P., Ruiz-Vera U.M., Rosenthal D.M. \& Vanloocke A. (2013) Modelling C3 photosynthesis from the chloroplast to the ecosystem. Plant Cell and Environment, 36, 1641-1657.

Bernacchi C.J., Singsaas E.L., Pimentel C., Portis A.R. \& Long S.P. (2001) Improved temperature response functions for models of Rubisco-limited photosynthesis. Plant Cell and Environment, 24, 253-259.

94 Bonan G.B., Lawrence P.J., Oleson K.W., Levis S., Jung M., Reichstein M., Lawrence D.M. \& Swenson S.C. (2011) Improving canopy processes in the Community Land Model version 4 (CLM4) using global flux fields empirically inferred from FLUXNET data. Journal of Geophysical Research-Biogeosciences, 116.

This article is protected by copyright. All rights reserved. 
Bown H.E., Watt M.S., Clinton P.W., Mason E.G. \& Richardson B. (2009) Partititioning concurrent influences of nitrogen and phosphorus supply on photosynthetic model parameters of Pinus radiata. Tree Physiology, 27, 335-344.

Brooks A. (1986) Effects of phosphorus nutrition on Ribulose-1,5-bisphosphate

702

703

704

705

706

707

708

709 carboxylase activation, photosynthetic quantum yield and amounts of some Calvin-cycle metabolites in spinach leaves. Australian Journal of Plant Physiology, 13, 221-237.

Brown S.L., Warwick N.W.M. \& Prychid C.J. (2013) Does aridity influence the morphology, distribution and accumulation of calcium oxalate crystals in Acacia (Leguminosae: Mimosoideae)? Plant Physiology and Biochemistry, 73, 219-228.

Bunce J.A. (2002) Sensitivity of infrared water vapor analyzers to oxygen concentration and errors in stomatal conductance. Photosynthesis Research, 71, 273-276.

Burch D.E., Singleton E.B. \& Williams D. (1962) Absorption line broadening in the infrared. Applied Optics, 1, 359-363.

Busch F.A. (2013) Current methods for estimating the rate of photorespiration in leaves. Plant Biology, 15, 648-655.

Campbell C.D. \& Sage R.F. (2006) Interactions between the effects of atmospheric $\mathrm{CO}_{2}$ content and P nutrition on photosynthesis in white lupin (Lupinus albus L.). Plant Cell and Environment, 29, 844-853.

Cernusak L.A., Hutley L.B., Beringer J., Holtum J.A. \& Turner B.L. (2011) Photosynthetic physiology of eucalypts along a sub-continental rainfall gradient in northern Australia. Agricultural and Forest Meteorology, 151, 1462-1470.

Close D.G. \& Beadle C.L. (2004) Total, and chemical fractions, of nitrogen and phosphorus in Eucalyptus seedling leaves: Effects of species, nursery fertiliser management and transplanting. Plant and Soil, 259, 85-95.

This article is protected by copyright. All rights reserved. 
Conn S. \& Gilliham M. (2010) Comparative physiology of elemental distributions in plants. Annals of Botany, 105, 1081-1102.

Crous K.Y., Quentin A.G., Lin Y.-S., Medlyn B.E., Williams D.G., Barton C.V.M. \& Ellsworth D.S. (2013) Photosynthesis of temperate Eucalyptus globulus trees outside their native range has limited adjustment to elevated $\mathrm{CO}_{2}$ and climate warming. Global Change Biology, 19, 3790-3807.

Denton M.D., Veneklaas E.J., Freimoser F.M. \& Lambers H. (2007) Banksia species (Proteaceae) from severely phosphorus-impoverished soils exhibit extreme efficiency in the use and re-mobilization of phosphorus. Plant Cell and Environment, 30, 1557-1565.

Domingues T.F., Meir P., Feldpausch T., Saiz G., Venendaal E.M., Schrodt F., Bird M., Djagblety G., Hien F., Camapore H., Diallo A., Grace J. \& Lloyd J. (2010) Colimitation of photosynthetic capacity by nitrogen and phosphorus in West Africa woodlands. Plant Cell and Environment, 33, 959-980.

Ellsworth D.S., Reich P.B., Naumburg E.S., Koch G.W., Kubiske M.E. \& Smith S.D. (2004) Photosynthesis, carboxylation and leaf nitrogen responses of 16 species to elevated $\mathrm{pCO}_{2}$ across four free-air $\mathrm{CO}_{2}$ enrichment experiments in forest, grassland and desert. Global Change Biology, 10, 2121-2138.

Ellsworth D.S., Thomas R.B., Crous K.Y., Palmroth S., Ward E., Maier C., DeLucia E.H. \& Oren R. (2012) Elevated $\mathrm{CO}_{2}$ affects photosynthetic responses in canopy pine and subcanopy deciduous trees over 10 years: a synthesis from Duke FACE. Global Change Biology, 18, 223-242.

Evans J.R. (1989) Photosynthesis and nitrogen relationships in leaves of C3 plants. Oecologia, 78, 9-19.

This article is protected by copyright. All rights reserved. 
Farquhar G.D., von Caemmerer S. \& Berry J.A. (2001) Models of photosynthesis. Plant Physiology, 125, 42-45.

Flexas J., Barbour M.M., Brendel O., Cabrera H.M., Carriqui M., Diaz-Espejo A., Douthe C.,

Dreyer E., Ferrio J.P., Gago J., Galle A., Galmés J., Kodama N., Medrano H., Niinemets Ü., Peguero-Pina J.J., Pou A., Ribas-Carbo M., Tomas M., Tosens T. \& Warren C.R. (2012) Mesophyll diffusion conductance to $\mathrm{CO}_{2}$ : An unappreciated central player in photosynthesis. Plant Science, 193, 70-84.

6 Franceschi V.R. \& Nakata P.A. (2005) Calcium oxalate in plants: formation and function. Annual Review of Plant Biology, 56, 41-71.

Galmés J., Flexas J., Keys A.J., Cifre J., Mitchell R.A.C., Madgwick P.J., Haslam R.P., Medrano H. \& Parry M.A.J. (2005) Rubisco specificity factor tends to be larger in plant species from drier habitats and in species with persistent leaves. Plant Cell and Environment, 28, 571-579.

Griffin E.A. \& Burbidge A.A. (1990) Description of the region. In: Nature Conservation, Landscape and Recreational Values of the Lesueur Area. (eds A.A. Burbidge, S.D. Hopper, \& D. Van Leeuwen), pp. 15-24. Environmental Protection Authority, Perth, WA Australia.

Groenendijk M., Dolman A.J., van der Molen M.K., Leuning R., Arneth A., Delpierre N., Gash J.H.C., Lindroth A., Richardson A.D., Verbeeck H. \& Wohlfahrt G. (2011) Assessing parameter variability in a photosynthesis model within and between plant functional types using global Fluxnet eddy covariance data. Agricultural and Forest Meteorology, 151, 22-38. 
Gu L. \& Sun Y. (2014) Artefactual responses of mesophyll conductance to $\mathrm{CO}_{2}$ and irradiance estimated with the variable J and online isotope discrimination methods. Plant Cell and Environment, 37, 1231-1249.

Hammond J.P. \& White P.J. (2011) Sugar signaling in root responses to low phosphorus availability. Plant Physiology, 156, 1033-1040.

Harley P.C. \& Sharkey T.D. (1991) An improved model of $\mathrm{C}_{3}$ photosynthesis at high $\mathrm{CO}_{2}$ : reversed $\mathrm{O}_{2}$ sensitivity explained by lack of glycerate reentry into the chloroplast. Photosynthesis Research, 27, 169-178.

Havrir E.A. (1984) Oxalate metabolism by tobacco leaf discs. Plant Physiology, 75, 505507.

Holford I.C.R. (1997) Soil phosphorus: its measurement, and its uptake by plants. Australian Journal of Soil Research, 35, 227-239.

Jacob J. \& Lawlor D.W. (1993) In vivo photosynthetic electron transport does not limit photosynthetic capacity in phosphate deficient sunflower and maize leaves. Plant Cell and Environment, 16, 785-795.

Joliffe P.A. \& Tregunna E.B. (1968) Effect of temperature, $\mathrm{CO}_{2}$ concentration, and light intensity on oxygen inhibition of photosynthesis in wheat leaves. Plant Physiology, 43, 902-906.

Kattge J., Knorr W., Raddatz T. \& Wirth C. (2009) Quantifying photosynthetic capacity and its relationship to leaf nitrogen content for global-scale terrestrial biosphere models. Global Change Biology, 15, 976-991.

Laing W.A., Ogren W.L. \& Hageman R.H. (1974) Regulation of soybean net photosynthetic $\mathrm{CO}_{2}$ fixation by interaction of $\mathrm{CO}_{2}, \mathrm{O}_{2}$, and ribulose $1,5-$ diphosphate carboxylase. Plant Physiology, 54, 678-685.

This article is protected by copyright. All rights reserved. 

ancient landscapes: high plant species diversity on infertile soils is linked to functional diversity for nutritional strategies. Plant and Soil, 334, 11-31.

Lambers H., Cawthray G.R., Giavalisco P., Kuo J., Laliberté E., Pearse S.J., Scheible W.R.,

799 Stitt M., Teste F. \& Turner B.L. (2012) Proteaceae from severely phosphorus-

800

801 impoverished soils extensively replace phospholipids with galactolipids and sulfolipids during leaf development to achieve a high photosynthetic

802 phosphorus-use-efficiency. New Phytologist, 196, 1098-1108.

803

Lambers H., Clode P., Hawkins H.-J., Laliberté E., R.S. O., Reddell P., Shane M.W., Stitt M. \& Weston P. (2015) Metabolic adaptations of the non-mycotrophic Proteaceae to soils with low phosphorus availability. In: Phosphorus Metabolism in Plants in the Post-genomic Era: From Gene to Ecosystem. (eds W.C. Plaxton \& H. Lambers), pp. 1-44. Wiley-Blackwell, London.

Li-Cor (2008) Using the Li-6400/Li-6400XT Portable Photosynthesis System. Li-Cor, Lincoln, NE USA. about the underlying limitations to photosynthesis? Procedures and sources of error. Journal of Experimental Botany, 54, 2393-2401. phosphorus nutrition in two-year-old maritime pine seedlings. Tree Physiology, 19, 707-715.

Manter D.K. \& Kerrigan J. (2004) A/C-i curve analysis across a range of woody plant species: influence of regression analysis parameters and mesophyll conductance. Journal of Experimental Botany, 55, 2581-2588.

This article is protected by copyright. All rights reserved. 
Matzek V. \& Vitousek P.M. (2009) N : P stoichiometry and protein : RNA ratios in vascular plants: an evaluation of the growth-rate hypothesis. Ecology Letters, 12, 765-771.

Merchant A., Peuke A.D., Keitel C., Macfarlane C., Warren C.R. \& Adams M.A. (2010) Phloem sap and leaf $\delta^{13} \mathrm{C}$, carbohydrates, and amino acid concentrations in Eucalyptus globulus change systematically according to flooding and water deficit treatment. Journal of Experimental Botany, 61, 1785-1793.

Niklas K.J., Owens T., Reich P.B. \& Cobb E.D. (2005) Nitrogen / phosphorus leaf stoichiometry and the scaling of plant growth. . Ecology Letters, 8, 636-642.

Ogren W.L. (1984) Photorespiration: pathways, regulation, and modification. Annual Review of Plant Physiology, 35, 415-442.

Paul M.J. \& Foyer C.H. (2001) Sink regulation of photosynthesis. Journal of Experimental Botany, 52, 1383-1400.

Piao S.L., Sitch S., Ciais P., Friedlingstein P., Peylin P., Wang X.H., Ahlstrom A., Anav A., Canadell J.G., Cong N., Huntingford C., Jung M., Levis S., Levy P.E., Li J.S., Lin X., Lomas M.R., Lu M., Luo Y.Q., Ma Y.C., Myneni R.B., Poulter B., Sun Z.Z., Wang T., Viovy N., Zaehle S. \& Zeng N. (2013) Evaluation of terrestrial carbon cycle models for their response to climate variability and to $\mathrm{CO}_{2}$ trends. Global Change Biology, 19, 2117-2132.

Pieters A.J., Paul M.J. \& Lawlor D.W. (2001) Low sink demand limits photosynthesis under $\mathrm{P}_{\mathrm{i}}$ deficiency. Journal of Experimental Botany, 52, 1083-1091.

Pons T., Flexas J., von Caemmerer S., Evans J.R., Genty B., Ribas-Carbo M. \& Brugnoli E. (2009) Estimating mesophyll conductance to $\mathrm{CO}_{2}$ : methodology, potential errors, and recommendations. Journal of Experimental Botany, 60, 2217-2234. 
Raven J.A. (2012) Protein turnover and plant RNA and phosphorus requirements in relation to nitrogen fixation. Plant Science, 188, 25-35.

Reich P.B., Oleksyn J. \& Wright I.J. (2009) Leaf phosphorus influences the photosynthesis-nitrogen relation: a cross-biome analysis of 314 species.

847 Oecologia, 160, 207-212.

848

Reumann S. \& Weber A.P.M. (2006) Plant peroxisomes respire in the light: some gaps of the photorespiratory $\mathrm{C}_{2}$ cycle have become filled - others remain. Biochim

850 Biophys Acta, 1763, 1496-1510.

851

852

857

858

859

860

861

862

863

864

865 Stitt M., Lunn J. \& Usadel B. (2010) Arabidopsis and primary photosynthetic metabolism $\mathrm{CO}_{2}$-insensitive photosynthesis in field grown plants. Plant Physiology, 84, 658664.

Sharkey T.D. (1985) Photosynthesis in intact leaves of C3 plants - physics, physiology and rate limitations. Botanical Review, 51, 53-105.

Sharkey T.D. (1988) Estimating the rate of photorespiration in leaves. Physiologia Plantarum, 73, 147-152.

Sharkey T.D., Bernacchi C.J., Farquhar G.D. \& Singsaas E.L. (2007) Fitting photosynthetic carbon dioxide response curves for $\mathrm{C} 3$ leaves. Plant Cell and Environment, 30, $1035-1040$.

Sharkey T.D. \& Vassey T.L. (1989) Low oxygen inhibition of photosynthesis is caused by inhibition of starch synthesis. Plant Physiology, 90, 385-387. - more than the icing on the cake. Plant Journal, 61, 1067-1091.

This article is protected by copyright. All rights reserved. 
Sulpice R., Ishihara H., Schlereth A., Cawthray G.R., Encke B., Giavalisco P., Ivakov A., Arrivault S., Jost R., Krohn N., Kuo J., Laliberte E., Pearse S.J., Raven J.A., Scheible W.R., Teste F., Veneklaas E.J., Stitt M. \& Lambers H. (2014) Low levels of ribosomal RNA partly account for the very high photosynthetic phosphorus-use efficiency of Proteaceae species. Plant Cell and Environment, 37, 1276-1298.

Tazoe Y., von Caemmerer S., Estavillo G.M. \& Evans J.R. (2011) Using tunable diode laser spectroscopy to measure carbon isotope discrimination and mesophyll conductance to $\mathrm{CO}_{2}$ diffusion dynamically at different $\mathrm{CO}_{2}$ concentrations. Plant Cell and Environment, 34, 580-591.

R Core Development Team (2014) A language and environment for statistical computing. R Foundation for Statistical Computing, Vienna, Austria. http://www.R-project.org.

Thomas D.S., Montagu K.D. \& Conroy J.P. (2006) Leaf inorganic phosphorus as a potential indicator of phosphorus status, photosynthesis and growth of Eucalyptus grandis seedlings. Forest Ecology and Management, 223, 267-274.

Veneklaas E.J., Lambers H., Bragg J., Finnegan P.M., Lovelock C.E., Plaxton W.C., Price C.A., Scheible W.R., Shane M.W., White P.J. \& Raven J.A. (2012) Opportunities for improving phosphorus-use efficiency in crop plants. New Phytologist, 195, 306320.

Vitousek P.M., Porder S., Houlton B.Z. \& Chadwick O.A. (2010) Terrestrial phosphorus limitation: mechanisms, implications, and nitrogen-phosphorus interactions. Ecological Applications, 20, 5-15.

von Caemmerer S. (2000) Biochemical Models of Leaf Photosynthesis. CSIRO Publishing, Collingwood, Victoria, Australia.

This article is protected by copyright. All rights reserved. 

Environment, 36, 1617-1630. biochemistry of photosynthesis and the gas exchange of leaves. Planta, 153, 376387.

896

897

898

899

900

901

902

903

904

905

906

907

908

909

910

911

912

913

914

915

Wohlfahrt G., Wullschleger S.D. \& Woodward F.I. (2014) The relationship of leaf photosynthetic traits - Vcmax and Jmax - to leaf nitrogen, leaf phosphorus, and specific leaf area: a meta-analysis and modeling study. Ecology and Evolution, 4, 3218-3235.

Walker B., Ariza L.S., Kaines S., Badger M.R. \& Cousins A.B. (2013) Temperature response of in vivo Rubisco kinetics and mesophyll conductance in Arabidopsis thaliana: comparisons to Nicotiana tabacum. Plant Cell and Environment, 36, 2108-2119.

Wang Y.P., Law R.M. \& Pak B. (2010) A global model of carbon, nitrogen and phosphorus cycles for the terrestrial biosphere. Biogeosciences, 7, 2261-2282.

Williams M., Rastetter E.B., Fernandes D.N., Goulden M.L., Shaver G.R. \& Johnson L.C. (1997) Predicting gross primary productivity in terrestrial ecosystems. Ecological Applications, 7, 882-894.

Wingler A., Lea P.J., Quick W.P. \& Leegood R.C. (2000) Photorespiration: metabolic pathways and their role in stress protection. Philosophical Transactions of the Royal Society London Series B, 355, 1517-1529.

Yang X. \& Post W.M. (2011) Phosphorus transformations as a function of pedogenesis: a synthesis of soil phosphorus data using Hedley fractionation method.

Biogeosciences, 8, 2907-2916.

This article is protected by copyright. All rights reserved. 
Zaehle S., Medlyn B.E., De Kauwe M.G., Walker A.P., Dietze M.C., Hickler T., Luo Y.Q.,

Wang Y.P., El-Masri B., Thornton P., Jain A., Wang S.S., Warlind D., Weng E.S.,

918

919

920

921

922
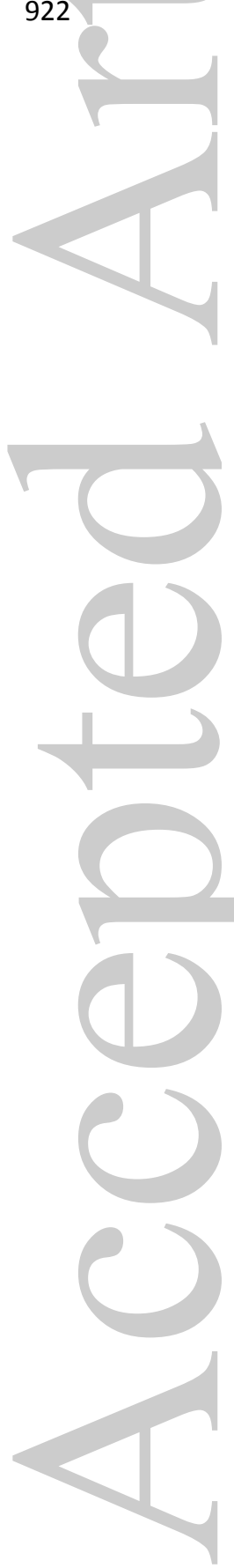

Parton W., Iversen C.M., Gallet-Budynek A., McCarthy H., Finzi A., Hanson P.J., Prentice I.C., Oren R. \& Norby R.J. (2014) Evaluation of 11 terrestrial carbonnitrogen cycle models against observations from two temperate Free-Air $\mathrm{CO}_{2}$ Enrichment studies. New Phytologist, 202, 803-822.

This article is protected by copyright. All rights reserved. 
Table 1. Description of species and sites included in the study along with number of individuals measured (N), the mean height that measurements were taken at, and the mean leaf thickness, leaf dry mass-to-area ratio, and total leaf P concentration per unit leaf area $\left(\mathrm{P}_{\mathrm{a}}\right)$. Data are means \pm s.e. The species name abbreviation is used to denote the different species in the figures.

\begin{tabular}{|c|c|c|c|c|c|c|c|c|}
\hline $\begin{array}{l}\text { Species name } \\
\text { and abbrev. }\end{array}$ & Type & Site & Location & $\mathrm{N}$ & $\begin{array}{l}\text { Height } \\
(\mathrm{m})\end{array}$ & $\begin{array}{l}\text { Leaf } \\
\text { thickness } \\
(\mu \mathrm{m})\end{array}$ & $\begin{array}{l}M_{a}(g \\
\left.m^{-2}\right)\end{array}$ & $\begin{array}{l}\text { Leaf } \mathrm{P}_{\mathrm{a}} \\
\left(\mathrm{mmol} \mathrm{P} \mathrm{m}^{-2}\right)\end{array}$ \\
\hline $\begin{array}{l}\text { Acacia } \\
\text { oblongifolia (A. } \\
\text { obl) }\end{array}$ & Native shrub & $\begin{array}{l}\text { Davies Park, } \\
\text { Springwood, NSW }\end{array}$ & $\begin{array}{l}33^{\circ} 42^{\prime} 28^{\prime \prime} \\
\mathrm{S}, 150^{\circ} 32^{\prime} \\
51^{\prime \prime} \mathrm{E}\end{array}$ & 4 & $1-2$ & 315 & $\begin{array}{l}192.5 \pm \\
11.8\end{array}$ & $2.5 \pm 0.5$ \\
\hline $\begin{array}{l}\text { Banksia } \\
\text { attenuata (B. } \\
\text { att) }\end{array}$ & Native shrub & $\begin{array}{l}\text { Lesueur National } \\
\text { Park, Jurien Bay, } \\
\text { WA }\end{array}$ & $\begin{array}{l}30^{\circ} 11^{\prime} 02^{\prime \prime} \\
\mathrm{S}, 115^{\circ} 09^{\prime} \\
27^{\prime \prime} \mathrm{E}\end{array}$ & 3 & 1 & 430 & $\begin{array}{l}271.5 \pm \\
19.5\end{array}$ & $2.7 \pm 0.4$ \\
\hline $\begin{array}{l}\text { B. serrata (B. } \\
\text { ser) }\end{array}$ & Native shrub & $\begin{array}{l}\text { Davies Park, } \\
\text { Springwood, NSW }\end{array}$ & $\begin{array}{l}33^{\circ} 42^{\prime} 28^{\prime \prime} \\
\mathrm{S}, 150^{\circ} 32^{\prime} \\
51^{\prime \prime} \mathrm{E}\end{array}$ & 3 & $1-2$ & 540 & $\begin{array}{c}207.2 \pm \\
3.7\end{array}$ & $1.7 \pm 0.2$ \\
\hline $\begin{array}{l}\text { Eucalyptus } \\
\text { dunnii (E. dun) }\end{array}$ & Plantation tree & $\begin{array}{l}\text { Hawkesbury Forest } \\
\text { Experiment, } \\
\text { Richmond NSW }\end{array}$ & $\begin{array}{l}33^{\circ} 36^{\prime} 40^{\prime \prime} \\
\text { S, } 150^{\circ} 44^{\prime} \\
27^{\prime \prime} \mathrm{E}\end{array}$ & 4 & 10 & 260 & $\begin{array}{c}135.6 \pm \\
2.6\end{array}$ & $6.1 \pm 0.5$ \\
\hline $\begin{array}{l}\text { E. fastigata (E. } \\
\text { fas) }\end{array}$ & $\begin{array}{l}\text { Native mature } \\
\text { sclerophyll woodland } \\
\text { tree }\end{array}$ & $\begin{array}{l}\text { Illawarra } \\
\text { escarpment, } \\
\text { Robertson, NSW }\end{array}$ & $\begin{array}{l}34^{\circ} 37^{\prime} 06^{\prime \prime} \\
\text { S, } 150^{\circ} 42^{\prime} \\
48^{\prime \prime} \mathrm{E}\end{array}$ & 5 & 25 & 300 & $\begin{array}{c}168.9 \pm \\
10.3\end{array}$ & $8.2 \pm 1.6$ \\
\hline $\begin{array}{l}\text { E. saligna (E. } \\
\text { sal) }\end{array}$ & Plantation tree & $\begin{array}{l}\text { Hawkesbury Forest } \\
\text { Experiment, } \\
\text { Richmond NSW }\end{array}$ & $\begin{array}{l}33^{\circ} 36^{\prime} 40^{\prime \prime} \\
S, 150^{\circ} 44^{\prime} \\
27^{\prime \prime} \mathrm{E}\end{array}$ & 3 & 9 & 318 & $\begin{array}{c}147.2 \pm \\
7.3\end{array}$ & $6.3 \pm 1.7$ \\
\hline $\begin{array}{l}\text { E. tereticornis } \\
\text { (E. ter) }\end{array}$ & $\begin{array}{l}\text { Native mature } \\
\text { sclerophyll woodland } \\
\text { tree }\end{array}$ & $\begin{array}{l}\text { Eucalyptus site } \\
\text { (EucFACE), } \\
\text { Richmond, NSW }\end{array}$ & $\begin{array}{l}33^{\circ} 36^{\prime} 57^{\prime \prime} \\
S^{\prime}, 150^{\circ} 44^{\prime} \\
16^{\prime \prime} \mathrm{E}\end{array}$ & 3 & 19 & 356 & $\begin{array}{c}208.3 \pm \\
11.7\end{array}$ & $7.3 \pm 0.3$ \\
\hline $\begin{array}{l}\text { E. todtiana (E. } \\
\text { tod) }\end{array}$ & $\begin{array}{l}\text { Native mature } \\
\text { woodland tree }\end{array}$ & $\begin{array}{l}\text { Lesueur National } \\
\text { Park, Jurien Bay, } \\
\text { WA }\end{array}$ & $\begin{array}{l}30^{\circ} 11^{\prime} 02^{\prime \prime} \\
S, 115^{\circ} 09^{\prime} \\
27^{\prime \prime} \mathrm{E}\end{array}$ & 3 & 2 & 530 & $\begin{array}{c}305.0 \pm \\
4.5\end{array}$ & $3.8 \pm 0.4$ \\
\hline $\begin{array}{l}\text { Liquidambar } \\
\text { styraciflua (L. } \\
\text { sty) }\end{array}$ & Plantation tree & $\begin{array}{l}\text { Hawkesbury } \\
\text { campus, Richmond, } \\
\text { NSW }\end{array}$ & $\begin{array}{l}33^{\circ} 36^{\prime} 57^{\prime \prime} \\
\text { S, } 150^{\circ} 45^{\prime} \\
06^{\prime \prime} \mathrm{E}\end{array}$ & 4 & 4 & 237 & $\begin{array}{c}111.9 \pm \\
2.0\end{array}$ & $6.6 \pm 1.5$ \\
\hline
\end{tabular}

This article is protected by copyright. All rights reserved. 


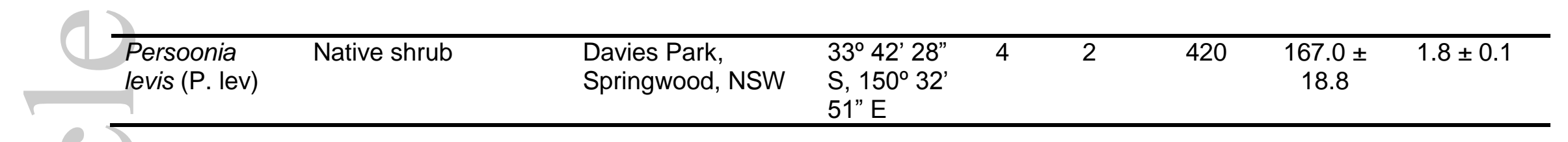

○

13

.

.

(1)

0

0

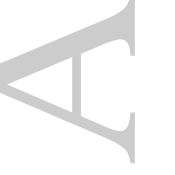

This article is protected by copyright. All rights reserved. 
Table 2. Summary of relationships between biochemical parameters of leaf photosynthetic capacity and leaf chemistry for ten species in this study. Leaf $N_{\text {area }}$ and $P_{\text {area }}$ are expressed in $\mathrm{mmol} \mathrm{m}^{-2}$.

\begin{tabular}{llll}
\hline Relationship & Equation & $\begin{array}{l}\text { Coefficient of } \\
\text { determination } \\
\left(\mathrm{R}^{2}\right)\end{array}$ & $\begin{array}{l}P \text { - } \\
\text { value }\end{array}$ \\
\hline$V_{\text {cmax }}$ by $\mathrm{N}_{\text {area }}$ & $N . S$. & - & 0.874 \\
$V_{\text {cmax }}$ by $\mathrm{P}_{\text {area }}$ & $N . S$. & 0.371 & 0.062 \\
$V_{\text {omax }}$ by $\mathrm{N}_{\text {area }}$ & $N . S$. & - & 0.361 \\
$V_{\text {omax }}$ by $\mathrm{P}_{\text {area }}$ & $V_{\text {omax }}=27.66+3.54^{*} \mathrm{P}_{\text {area }}$ & 0.394 & 0.052 \\
$J_{\max }$ by $\mathrm{N}_{\text {area }}$ & $N . S$. & & 0.322 \\
$J_{\max }$ by $\mathrm{P}_{\text {area }}$ & $J_{\max }=88.56+400.99^{*} \mathrm{P}_{\text {area }}$ & 0.656 & 0.045 \\
$T_{\mathrm{p}}$ by $\mathrm{N}_{\text {area }}$ & $N . S$. & & 0.201 \\
$T_{\mathrm{p}}$ by $\mathrm{P}_{\text {area }}$ & $T_{\mathrm{p}}=6.51+14.64^{*} \mathrm{P}_{\text {area }}$ & - & 0.035 \\
\hline
\end{tabular}

This article is protected by copyright. All rights reserved. 


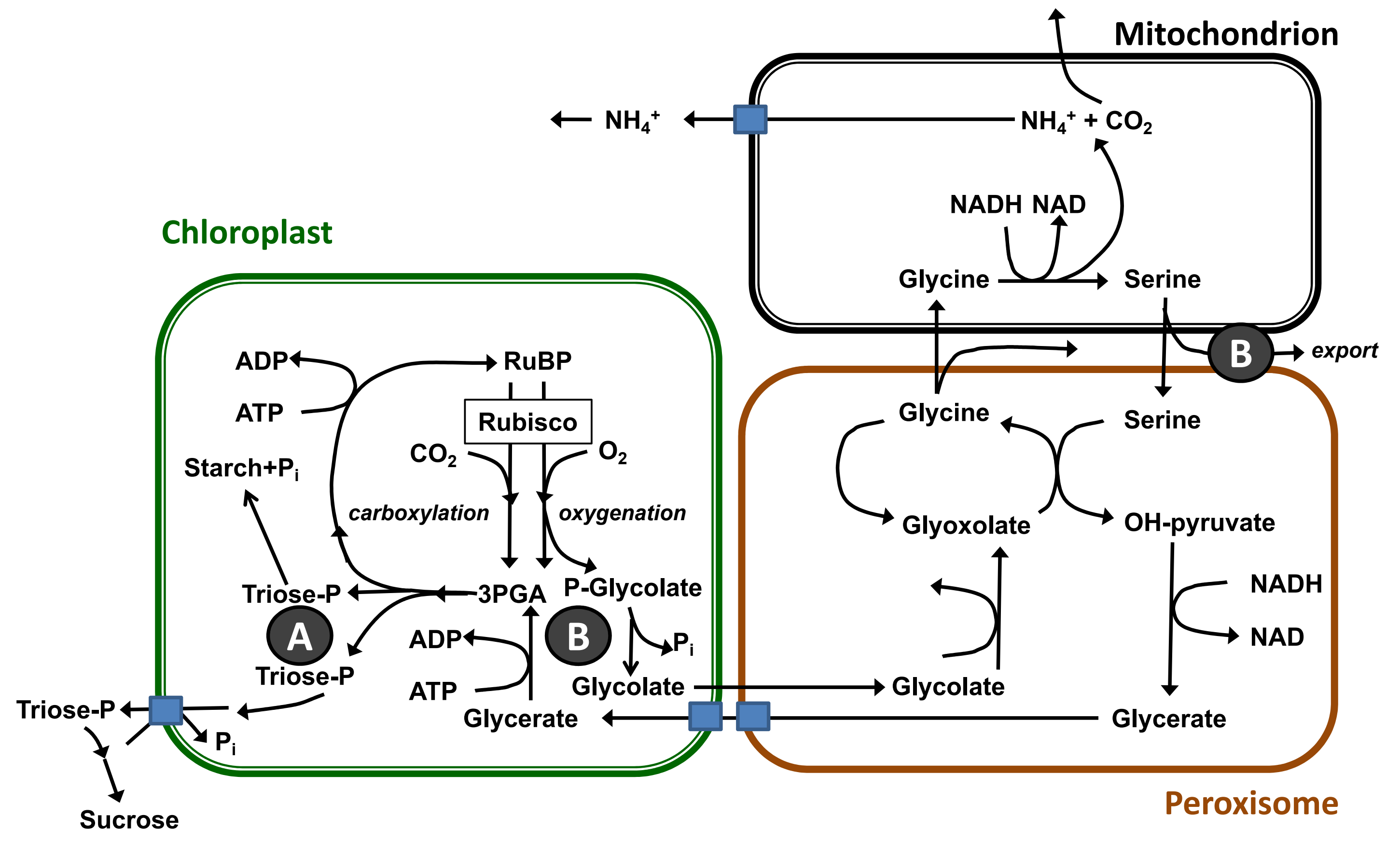



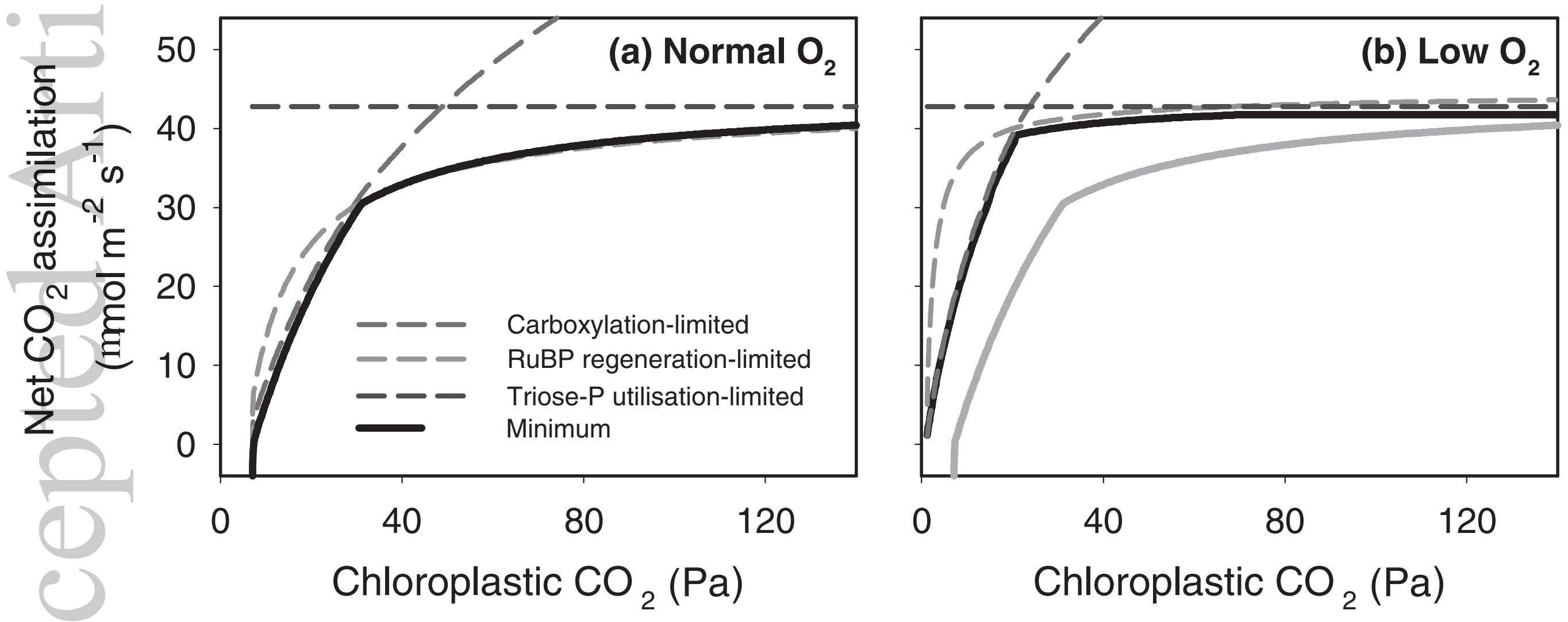

FIG 2. 



FIG 3. 

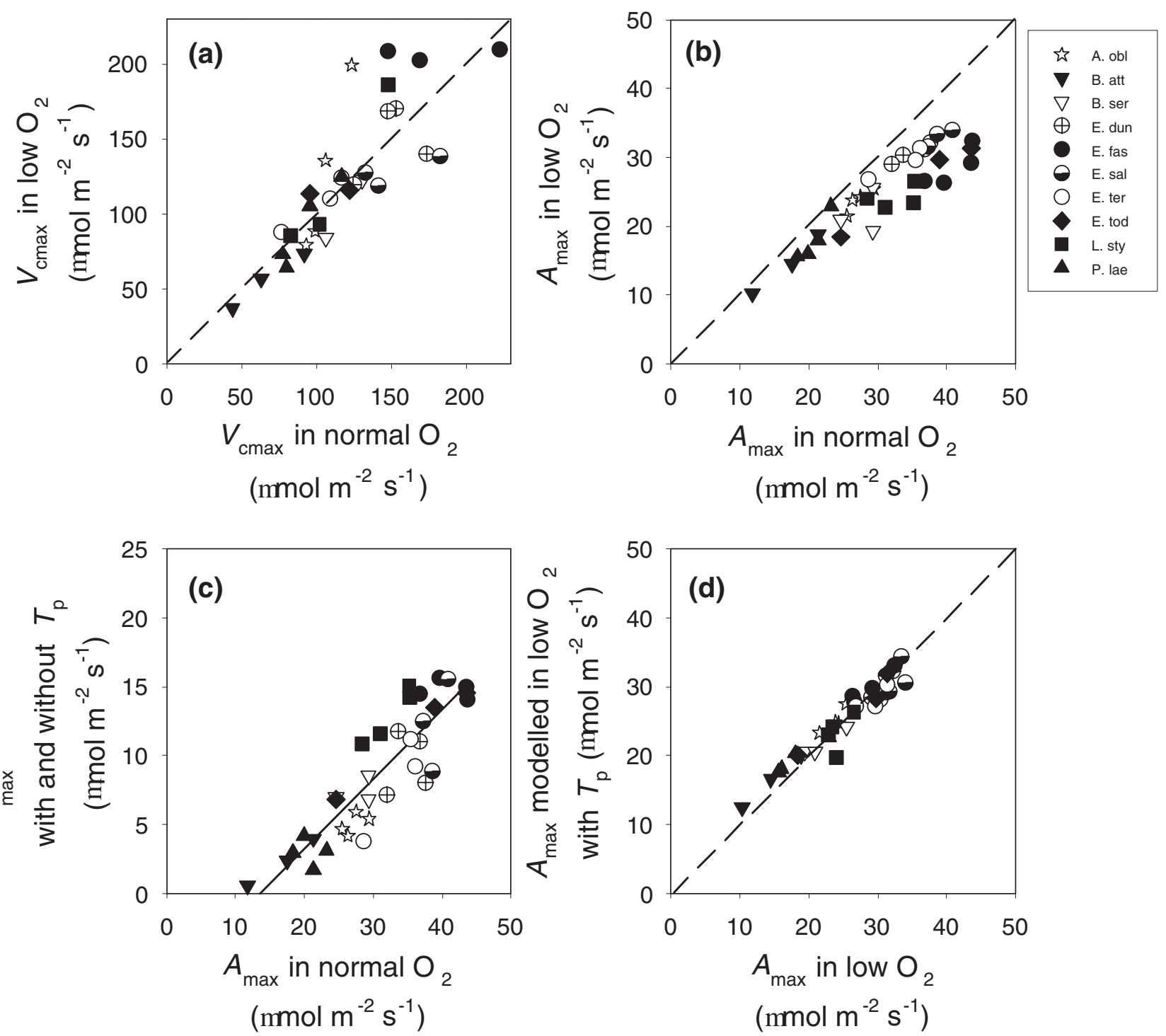

FIG 4. 


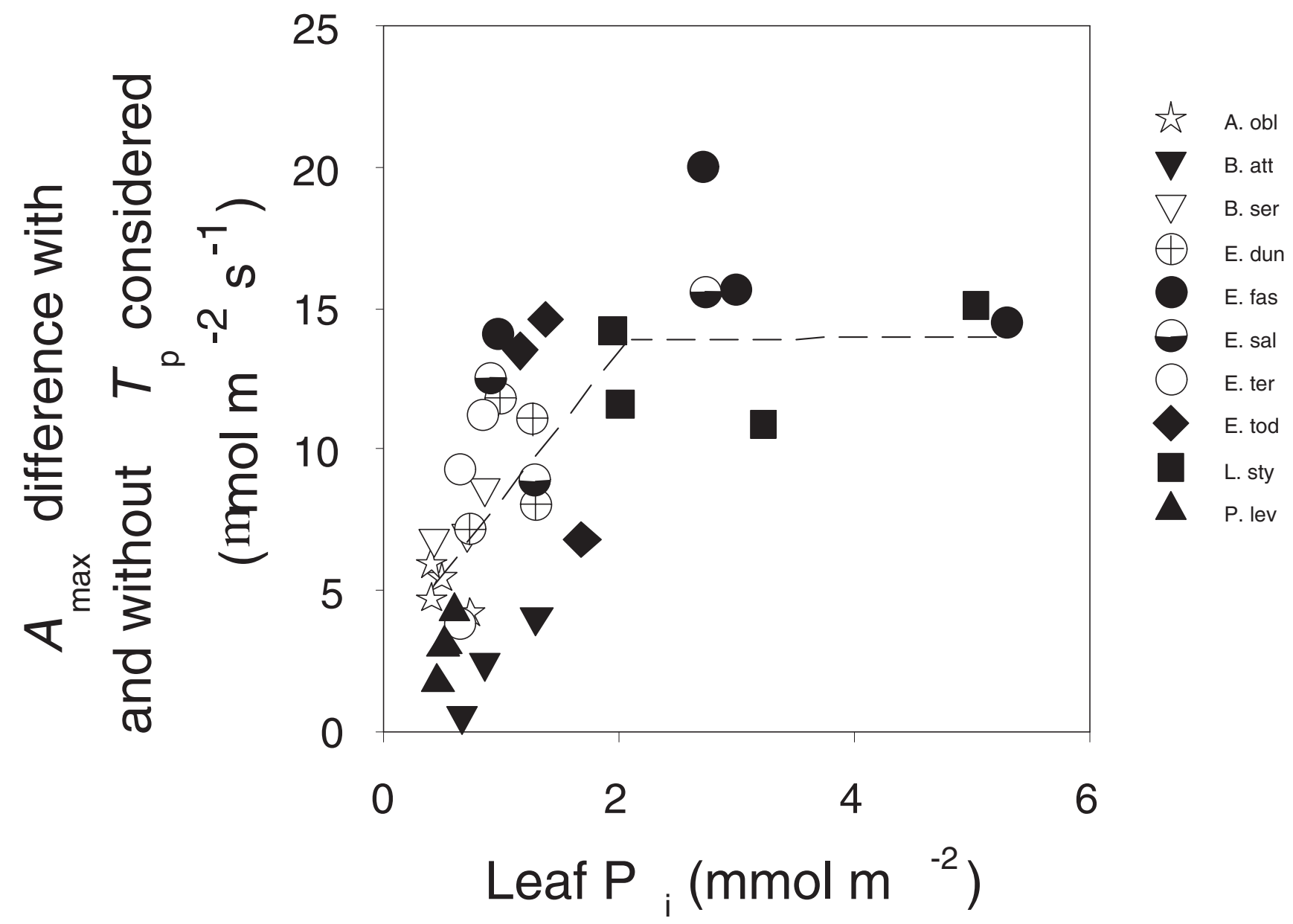

FIG 5. 

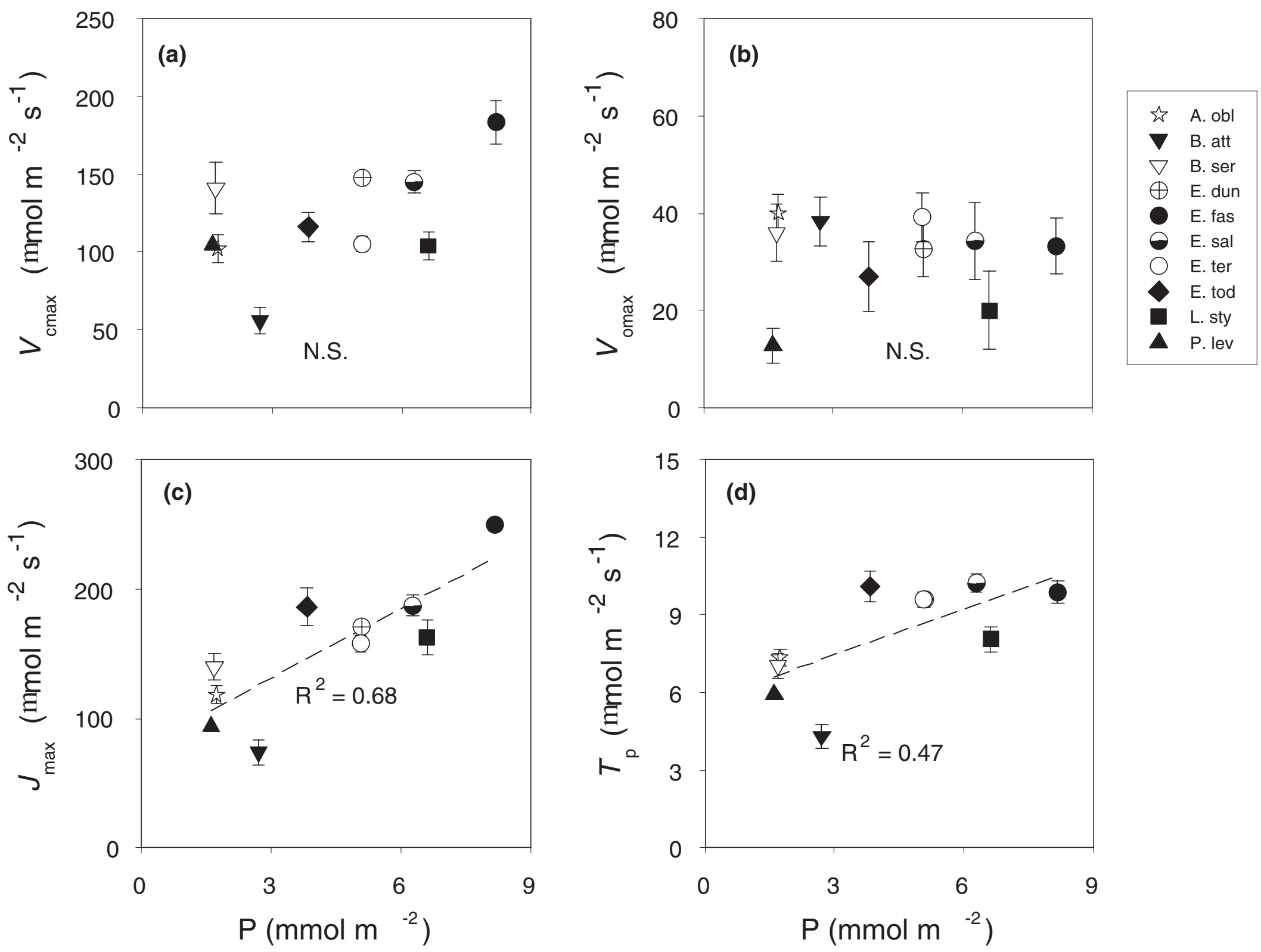

FIG 6. 